\title{
Frequencies of Circular Units of Nucleolar DNA in Oocytes of Two Insects, Acheta domesticus and Dytiscus marginalis, and Changes of Nucleolar Morphology during Oogenesis
}

\author{
Division of Membrane Biology and Biochemistry, \\ Institute of Experimental Pathology, \\ German Cancer Research Center, \\ D-6900 Heidelberg, Federal Republic of Germany
}

M. F. TRENDELENBURG, W. W. FRANKE, and U. SCHEER

Received July 1976/Accepted August 1976

The organization of the extrachromosomal nucleolar material in oocytes of two insect species with different ovary types, the house cricket Acheta domesticus (panoistic ovary) and the water beetle Dytiscus marginalis (meroistic ovary), was studied with light and electron microscopic techniques. Stages early in oogenesis were compared with fully vitellogenic stages (mid-to-late diplotene). The arrangement of the nucleolar material undergoes a marked change from a densely aggregated to a dispersed state. The latter was characterized by high transcriptional activity. In spread and positively stained preparations of isolated nucleolar material, a high frequency of small circular units of transcribed rDNA was observed and rings with small numbers (1-5) of pre-rRNA genes were predominant. The observations suggest that the "extra DNA body" observed in early oogenic stages of both species represents a dense aggregate of numerous short circular units of nucleolar chromatin, with morphological subcomponents identifiable in ultrathin sections. These apparently remain in close association with the chromosomal nucleolar organizer(s). The observations further indicate that the individual small nucleolar subunit circles dissociate and are dispersed as actively transcribed rDNA units later in diplotene. The results are discussed in relation to principles of the ultrastructural organization of nucleoli in other cell types as well as in relation to possible mechanisms of gene amplification.

\section{Introduction}

Production of extrachromosomal copies of genes coding for the precursors of ribosomal RNAs (rRNAs), i.e. rDNA amplification, has been described in several cell systems that are characterized by high rates of ribosome formation such as oocytes of various amphibia, insects and fishes (for references see [1-5]). Selective amplification of rDNA has also been reported in nuclei of proliferating cells and plasmodia, for example the macronucleus of the ciliate, Tetrahymena pyriformis [6-8], in the plasmodia of the slime mold, Physarum polycephalum [9] and in somatic amphibian cells [10]. Detailed molecular biological studies have shown that such amplified rDNA gene units can occur both in apparently linear molecules (see in particular Tetrahymena pyriformis $[11,12])$ and in covalently closed circles of different sizes that contain variable numbers of pre-rRNA genes (amphibia [10, 13-17]; insects [18-20]; slime molds [9]; Tetrahymena [7]). In these studies it has further been demonstrated that relatively small circular units containing only a few (up to ten) genes can occur side by side with usually longer linear molecules in one and the same cell system. The existence of circular units containing extrachromosomal nucleolar genes is of utmost importance to discussions of the mechanism of gene amplification. Most recent interpretations have favoured a concept whereby amplification occurs via a "rolling circle" process $[15,16,21,22]$.

Among insects, three types of ribosome production during oogenesis have been distinguished (for reviews see [23, 24]): (1) production in the oocyte using pre- 
rRNA copies present in the oocyte nucleus (panoistic ovaries; for refs. see [25-30]), (2) production of complete ribosomes in nurse cells and transport to the ooplasm (all telotrophic and many of the polytrophicmeroistic ovarioles), and (3) contributions to ooplasmic ribosomes from both oocyte and nurse cells (these include but are not restricted to examples with an essentially polytrophic-meroistic organization; see refs. given above). Examples of rDNA amplification have been described in the panoistic ovaries of the house cricket, Acheta domesticus [2, 28-31], in the meroistic ovaries of the cranefly Tipula and in the water beetles Dytiscus and Colymbetes [1, 18, 24, 32, 33]; for related earlier observations see [34-36]. Large, Feulgen-positive aggregate masses, which indicate the presence of extrachromosomal rDNA, have been described recently for oocytes of two Coleoptera, the gyrinid Gyrinus natator and the staphylinid Creophilus maxillosus [37-39], as well as for oocytes of the neuropteran Chrysopa perla $[40,41]$. The present article details the cytology of amplified nucleolar material in two representatives of different oogenic types, the panoistic Acheta domesticus and the meroistic Dytiscus marginalis, with emphasis on the organization of the rDNA units as revealed in spread preparations of oocyte nucleoli. We demonstrate that a high proportion, if not all, of the amplified rDNA in the oocytes of both organisms is present as small circular units that contain variable gene numbers. These units are aggregated in large dense masses during early oogenesis but are dispersed and in full transcription in midto-late diplotene stages.

\section{Methods}

Young Acheta domesticus females were taken from a laboratory culture, kindly provided by Dr. H.-J. Bode (Institute of Zoology, University of Heidelberg). Dytiscus marginalis females were collected in small ponds near Heidelberg or were a gift of Dr. H. Schildknecht (Institute of Organic Chemistry, University of Heidelberg).

For light and electron microscopic examinations of sections, ovarioles from both species were dissected from the animals and immediately fixed in $2.5 \%$ glutaraldehyde buffered with $0.05 \mathrm{M}$ sodium cacodylate $(\mathrm{pH} 7.2)$ for $1 \mathrm{~h}$ at $4^{\circ} \mathrm{C}$, washed several times in cold buffer, dehydrated by the acetone vapour method [42] and embedded in Epon 812. For the Feulgen reaction 1-2 $\mu \mathrm{m}$ thick sections were treated essentially as described by Spring et al. [43]. The time for optimal hydrolysis was $15 \mathrm{~min}$. Thin $(1-2 \mu \mathrm{m})$ and ultrathin sections were prepared with a Reichert ultramicrotome OmU 3. The ultrathin sections were stained in aqueous uranyl acetate and poststained with lead citrate. Micrographs were taken with a Zeiss EM 10 (Carl Zeiss, Oberkochen, Germany) or Siemens electron microscopes IA or 101.

For spread preparations nuclei were isolated from oocytes and nuclear contents spread according to the technique of Miller and Beatty [13] as previously described for oocyte nuclei from Acheta [44] and Dytiscus $[19,20]$. In some spread experiments oocyte nuclei were isolated in $\mathrm{NaCl} / \mathrm{KCl}$ "K-Ringer" [45] and further treated with $0.5 \mathrm{mM}$ sodium borate buffer $(\mathrm{pH} 9)$ containing $0.3 \%$ Sarkosyl NL-30. These preparations were additionally rotary-shadowed with gold-palladium at an angle of about $7^{\circ}$ (cf. e.g. the methodological section in [46]). Length measurements of axial contours were performed as outlined in previous publications [20, 47].

\section{Results}

\section{Light and Electron Microscopy of the Oocyte Nuclei of Dytiscus marginalis after Fixation in situ}

Early stages of oogenesis of dytiscid beetles (e.g. those corresponding to oocyte stages $1-2$ in the classification

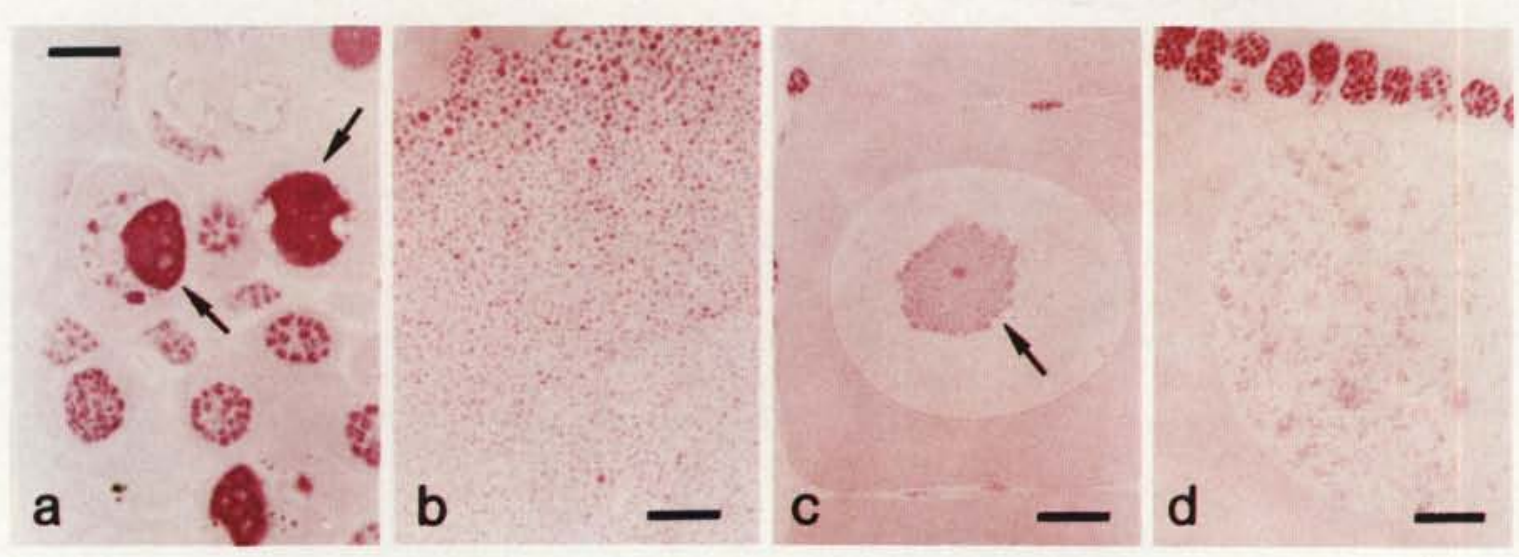

Fig. 1a-d. Feulgen staining in thick sections through oocyte nuclei of Dytiscus marginalis and Acheta domesticus at different stages of oogenesis. Oocyte nuclei in the germarium of Dytiscus (a): large, positively stained nucleolar aggregates (arrows) at the pachytene stage; note also intense staining in the surrounding nurse cell nuclei. (b) Sector of the large diplotene oocyte nucleus with characteristic dispersed state of nucleolar material; note high number of small nucleolar bodies and their relatively homogeneous size distribution; upper left: part of nuclear envelope can be identified. Feulgen staining of $A$ cheta oocyte nuclei at early diplotene (c) also shows the aggregate nucleolar body located in the nuclear center (arrow). Later in oogenesis (e.g. at late diplotene) (d) dispersion of the nucleolar material into clusters of tiny, Feulgen-positive bodies is noted (note also the intense staining of the nuclei of the follicle and germinal sheath epithelia in (c) and (d)). Scales: $10 \mu \mathrm{m}$. All figures $\times 720$ 
according to [48]) are characterized by the formation of a large intranuclear body which is intensely stained with both the Feulgen procedure (Fig. 1a) and the uranyl and lead stains used in electron microscopy (Figs. 2 and 3).
Such conspicuous "extra DNA bodies" have not only been observed in dytiscid beetles but also in other beetles $[24,25,33,48,49]$ and in taxonomically rather distant insect species (for refs. see Introduction and

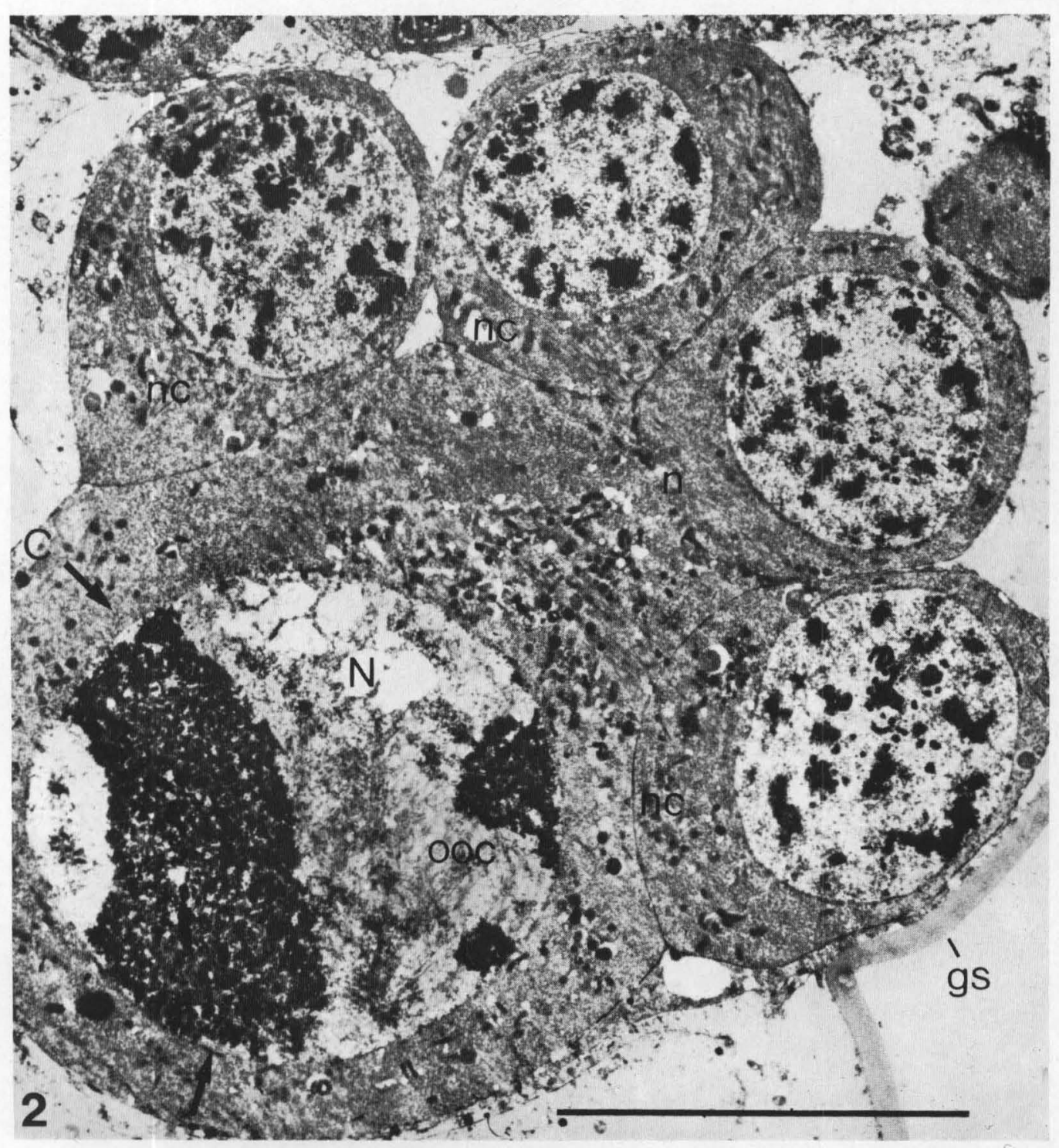

Fig. 2. Survey electron micrograph of section through middle region of a germarium of Dytiscus marginalis. Typical pachytene oocyte (ooc) is surrounded by a series of nurse cells $(n c)$. In the oocyte nucleus $(N)$ the conspicuous aggregate of nucleolar DNA spans the whole nucleus (arrows) and appears to be attached to the nuclear envelope. Note also densely stained chromatin material. $C$ : cytoplasm of oocyte; gs: germarial sheath, tunica propria. Scale: $10 \mu \mathrm{m} . \times 5300$

Fig. 3a, b. Nucleus $(N)$ of Dytiscus oocyte at pachytene stage as revealed at higher magnification. Note characteristic subarchitecture of large aggregate of condensed nucleolar material ( $\mathrm{cNo}$ ). This aggregate displays a mosaic of heavily stained dense aggregates of variable sizes (a); some are denoted by arrowheads in (b) that are embedded in a more loosely packed, less intensely stained fibrillar matrix. Nucleolar body appears to be attached to the nuclear envelope in distinct regions (pair of arrows in (b)). Chromosomal material $(\mathrm{CH})$ is distributed over the remaining nuclear region and reveals small aggregates of densely stained material, some of which are in close association with the nuclear envelope. (NE: arrows in (a)), and loosely arranged fibrils which in some regions seem to be aggregated into coils. $C$ : cytoplasm; $N$ : oocyte nucleus. Scales: $5 \mu \mathrm{m}$ in Figure 3 a and $2 \mu \mathrm{m}$ in Figure 3 b. (a) $\times 7300$; (b) $\times 18,800$ 


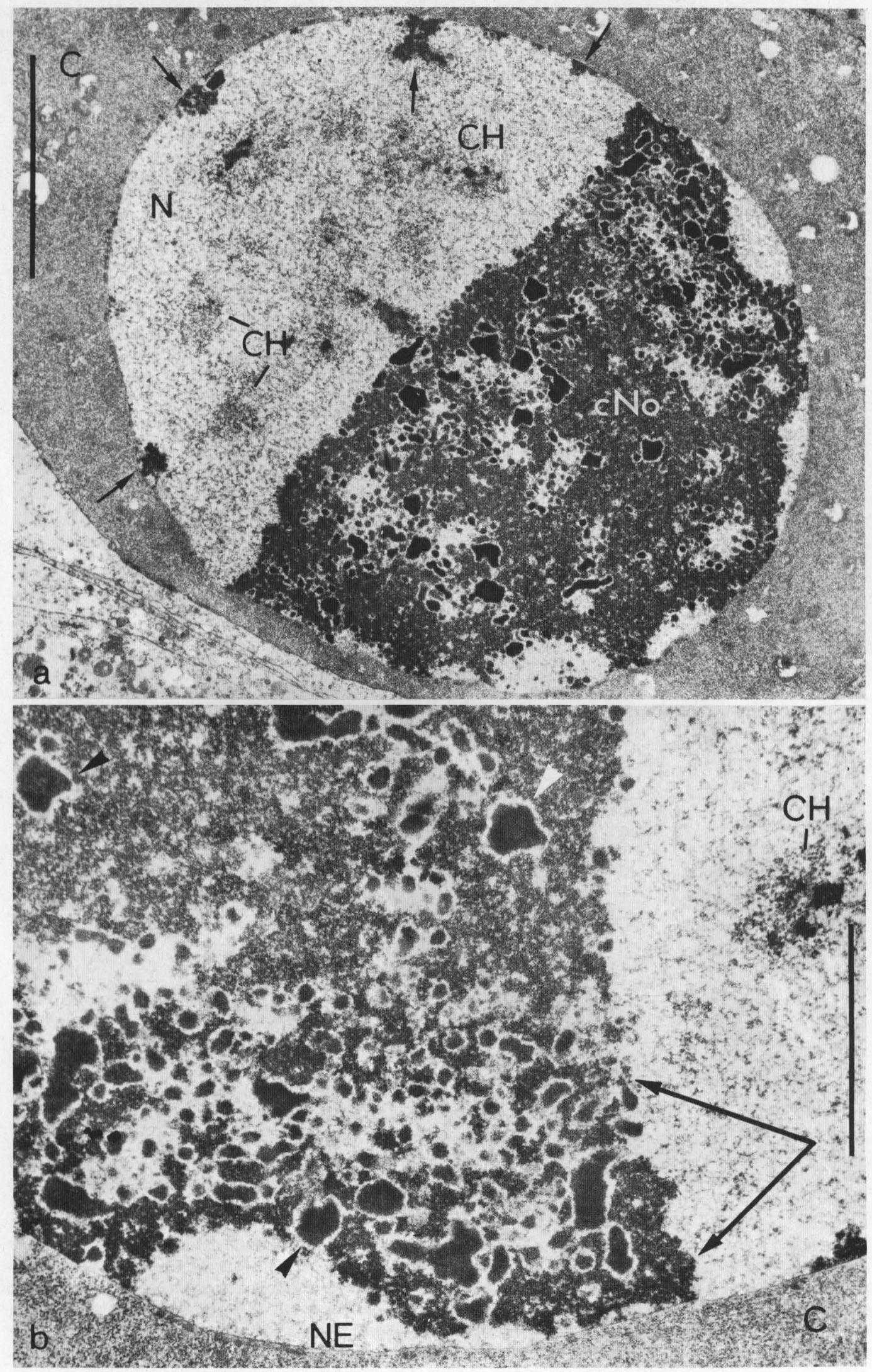

Fig. 3. Legend see page 135 


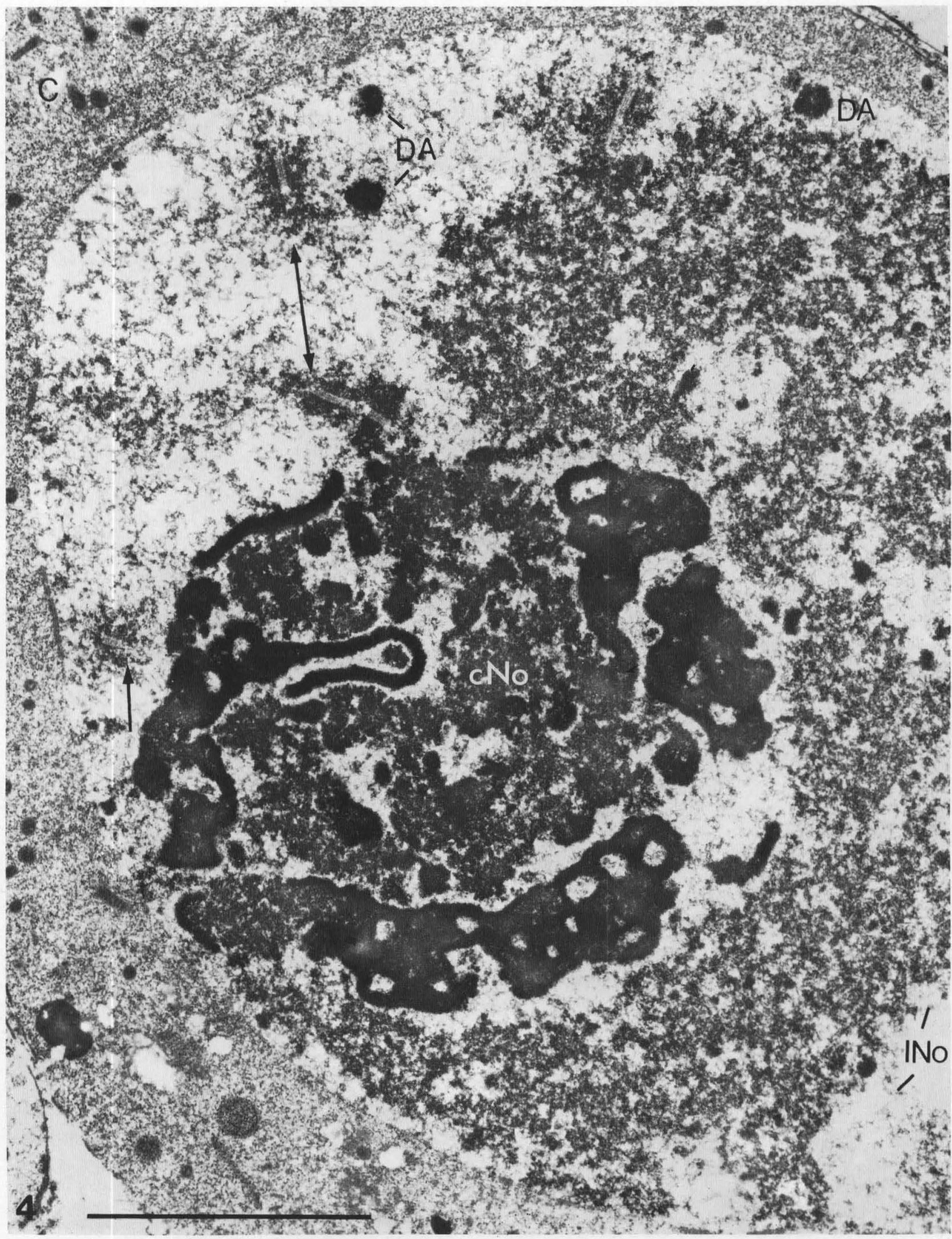

Fig. 4. Legend see page 139 


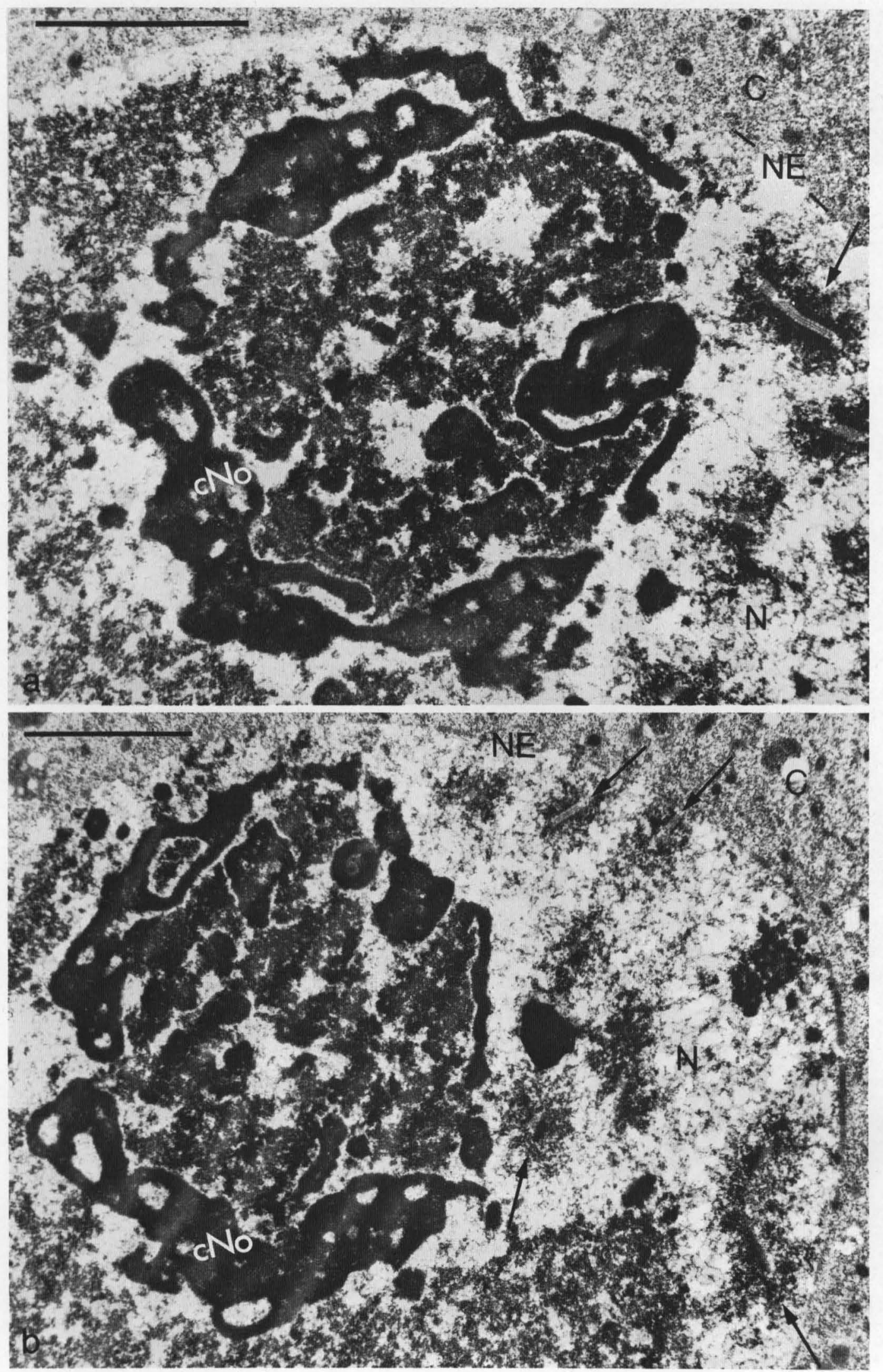

Fig. 5. Legend see page 139 
below). In some species including Dytiscus, such extraDNA bodies have been shown to contain sequences coding for rRNA and thus to represent a nucleolar structure [33]. In early oogenesis of Dytiscus, this large intranuclear body usually appears as a crescent or a band that extends through the entire nucleus and frequently appears laterally attached to the nuclear envelope
(Figs. 2 and 3). At higher magnification (Figs. 3-5) the large nucleolar mass is identified as an aggregate composed of (1) distinct, irregularly shaped units of variable sizes (up to about $1.3 \mu \mathrm{m}$ in diameter) which stain most intensely and are usually surrounded by a "halo" of electron transparency (Figs. 3-6), (2) an indistinct moderately stained fibrillar ground substance surrounding

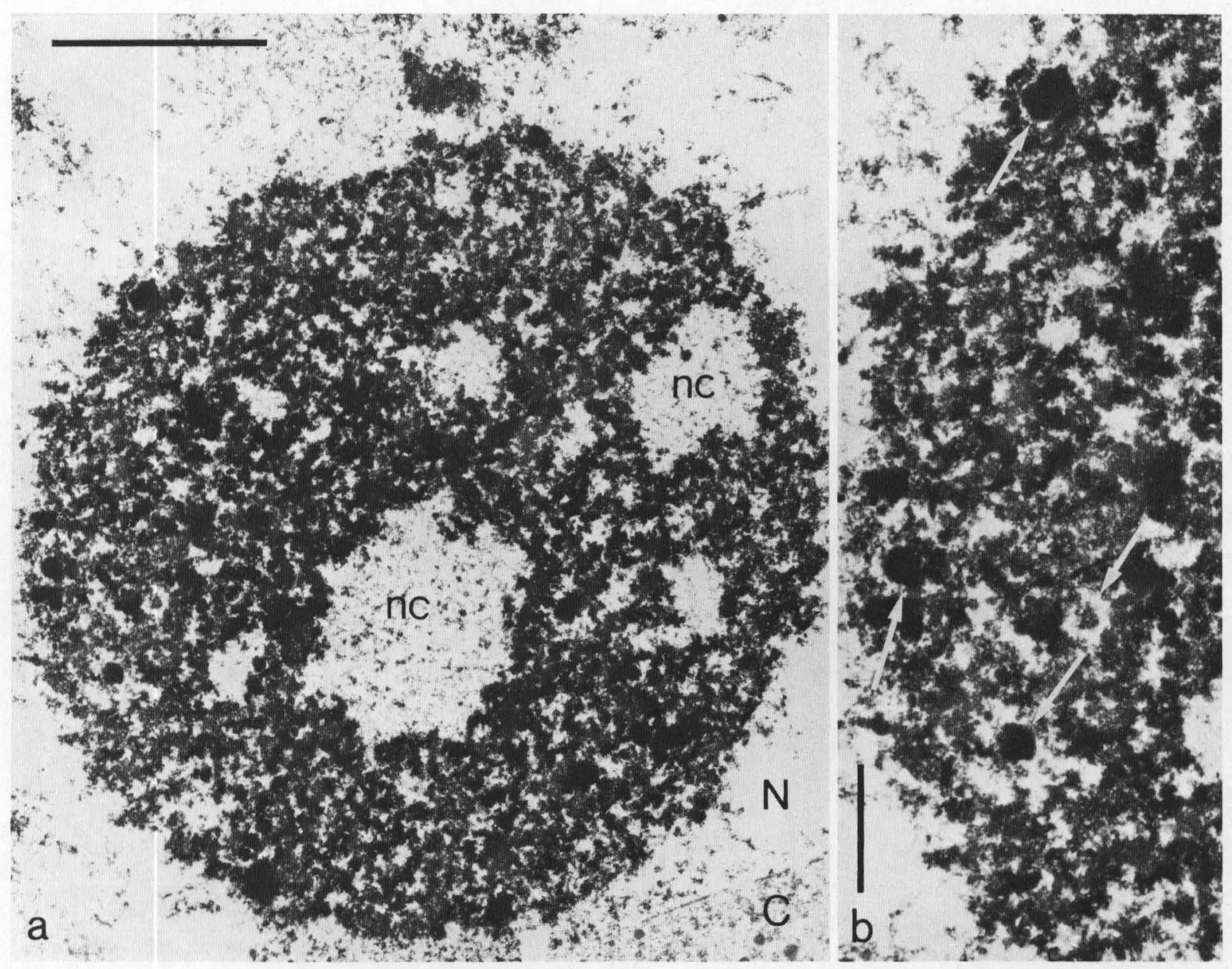

Fig. 6a, b. Section grazing to the periphery of a Dytiscus oocyte nucleus at late pachytene, showing the looser packing of the dense "nucleolar core material" which appears here in the form of small granular aggregates and fibrillar coils. Note also appearance of intranucleolar cavities ( $n c$ ) filled with very loosely packed thin filaments. Arrows in (b) denote some of the small dense granules which occasionally reveal a "halo" of reduced contrast. N: nucleus; $C$ : cytoplasm; $n c$ : nucleolar cavity. Scales: $3 \mu \mathrm{m}$ (a) and $1 \mu \mathrm{m}$ (b). (a) $\times 9500$; (b) $\times 16,500$

Fig. 4. Electron micrograph showing another aspect of nuclear organization of pachytene oocyte of Dytiscus (here in an almost median section). The nucleolar mass contains a central "core" ( $c \mathrm{No}$ ) constituted by intensely stained aggregates, some of which reveal a bandlike shape. This core aggregate is embedded in, and surrounded by, a large "cap" zone composed of loosely packed fibrillar material( $(N o$ ). Dispersed in nuclear sap are small (up to $0.5 \mu \mathrm{m}$ in diameter) dense aggregates (DA), probably of chromosomal chromatin. Arrows: some of the synaptinemal complexes. Scale: $3 \mu \mathrm{m}$ $(\times 17,000)$

Fig. 5a, b. Serial sections adjacent to that shown in the previous figure, demonstrating details of subarchitecture of "core body" of nucleolar aggregate. Note that most of the very dense nucleolar material is arranged in large bands and sheets that seem to constitute a capsule-like structure around the more loosely packed nucleolar core components (Fig. 4; 8a and b). In the nucleoplasm, large synaptinemal regions of paired chromosomes can be identified (arrows), and in some places their attachment to the nuclear envelope ( $N E$ ) can be visualized (e.g. upper arrows in (b)). $N$ : oocyte nucleus; $C$ : cytoplasm. Scales: $2 \mu \mathrm{m}$. (a) $\times 17,000$; (b) $\times 13,500$ 

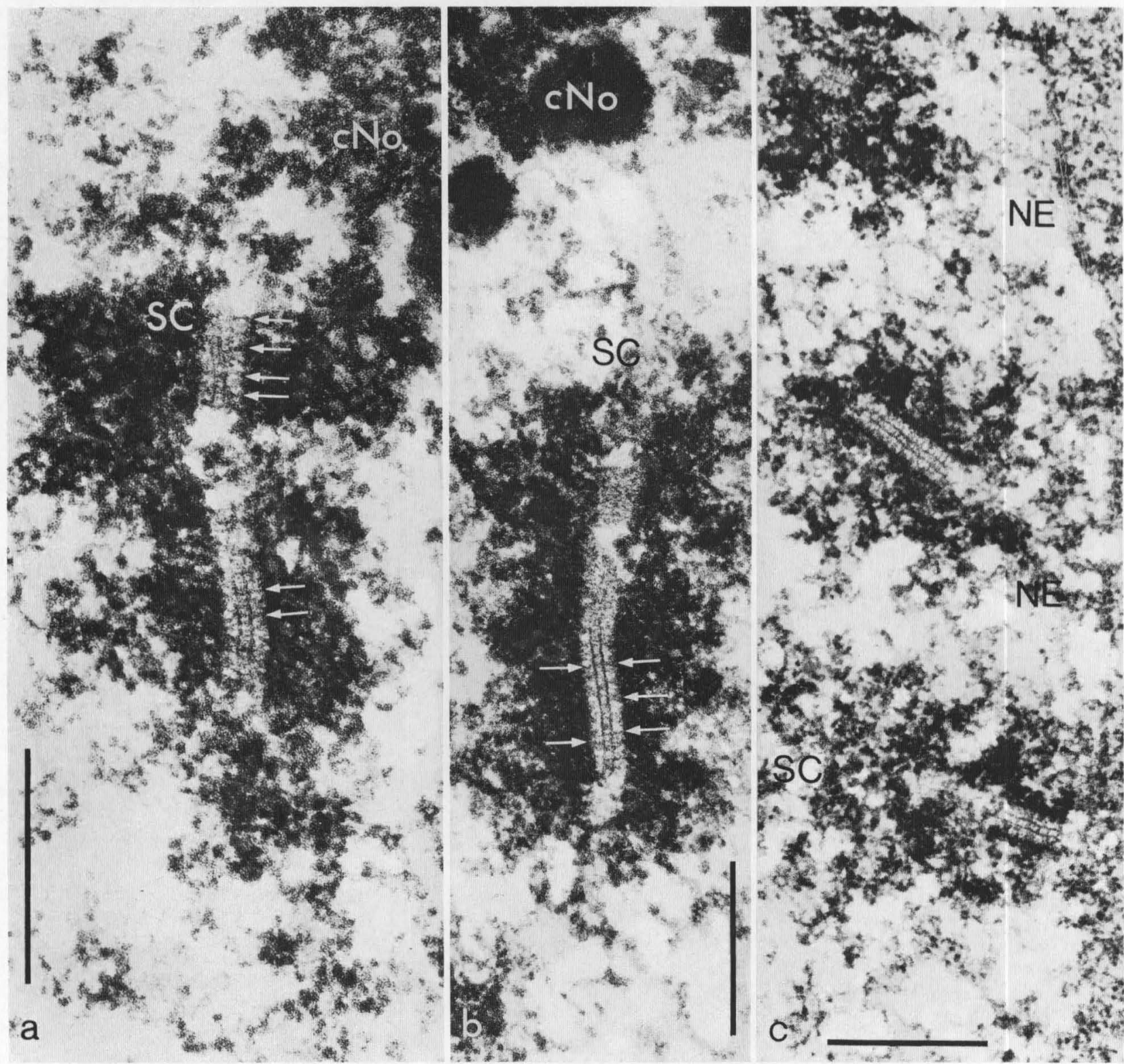

Fig. 7a-c. Details of the associations of the synaptinemal complex of the pachytene chromosomes with the condensed nucleolar aggregate ( $c$ No) and, in their terminal regions, with the nuclear envelope ( $N E$; e.g. in c). In all figures the characteristic substructure of the synaptinemal complexes (sc) is recognized, in particular the ladder-like configuration of the central element and the periodically arranged "transverse filaments" that also span the space between the central element and the lateral elements (denoted in some regions by arrows). Note also the blocks of condensed chromatin ("heterochromatin") associated with the periphery of some of the SCs (for refs. on the terminology of SC structure see text). Scales: $0.5 \mu \mathrm{m}$. (a) $\times 70,000$; (b) $\times 54,000 ;$ (c) $\times 48,000$

Fig. 8a-c. Survey electron micrographs of the peripheral part of the late diplotene nucleus of the Dytiscus oocyte. The whole, now very large nucleus is rather homogeneously filled with numerous small, densely stained nucleolar bodies. Note that two size classes can be distinguished, namely small aggregates of about $100 \mathrm{~nm}$ diameter and larger ones which range from $0.3 \mu \mathrm{m}$ to about $1.5 \mu \mathrm{m}$ in size (modal distribution with a mean peak diameter of $0.9 \mu \mathrm{m}$ ). (b) shows the characteristic ultrastructure of these nucleolar bodies which when centrally sectioned reveal a "ring-shaped" organization ( $a r$ row in b). Occasionally strands of less densely stained material, probably representing chromosomal strands, are seen associated with nuclear envelope (see e.g. structure denoted by arrows, in c). $N$ : nucleus; $C$ : cytoplasm. Scales: $10 \mu \mathrm{m}$ (a), $1 \mu \mathrm{m}$ (b) and $5 \mu \mathrm{m}$ (c). (a) $\times 3100$;(b) $\times 18,500$; (c) $\times 4800$ 


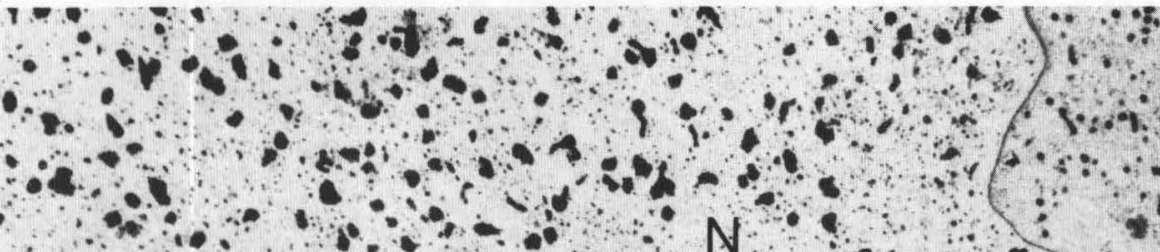

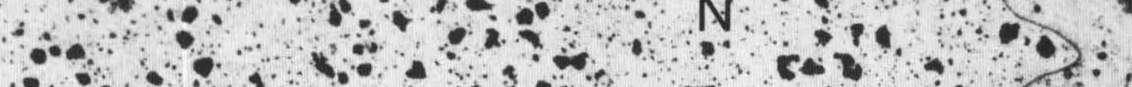

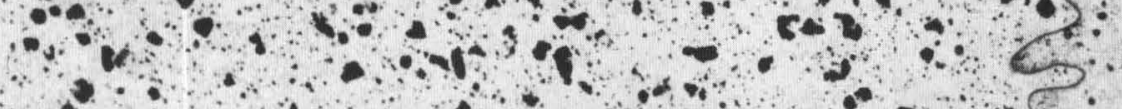
$+40+2 c^{2}-2$

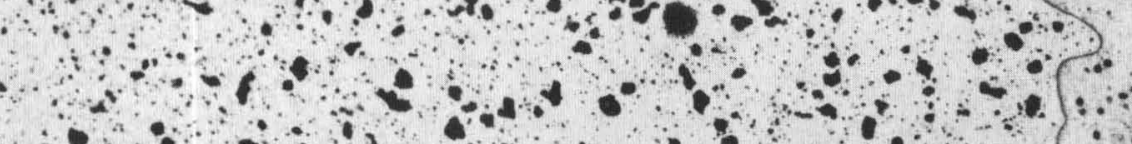

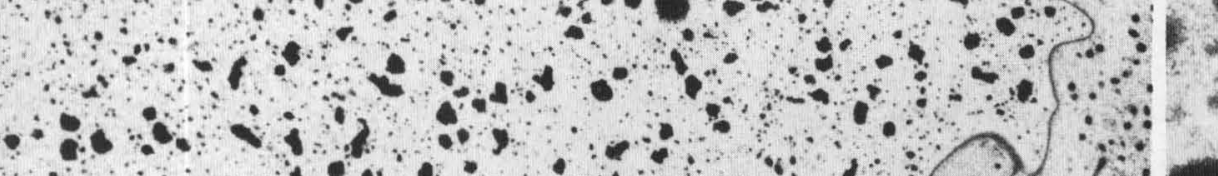

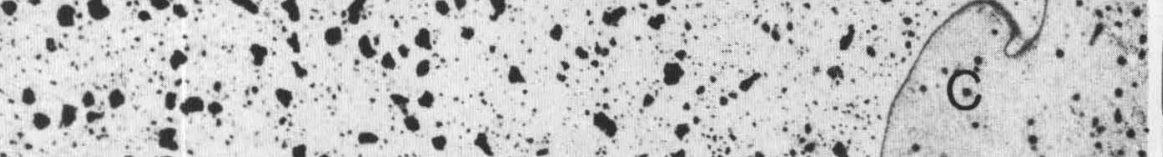

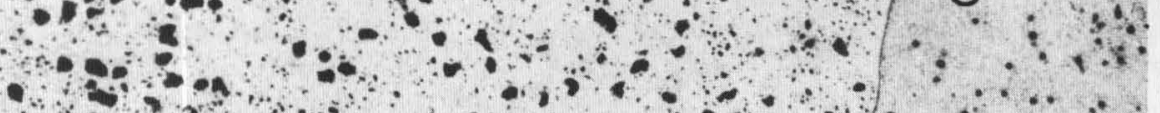

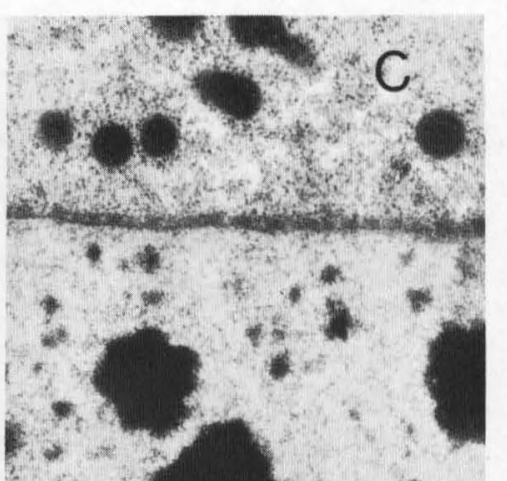
$4-\infty-\infty-2$

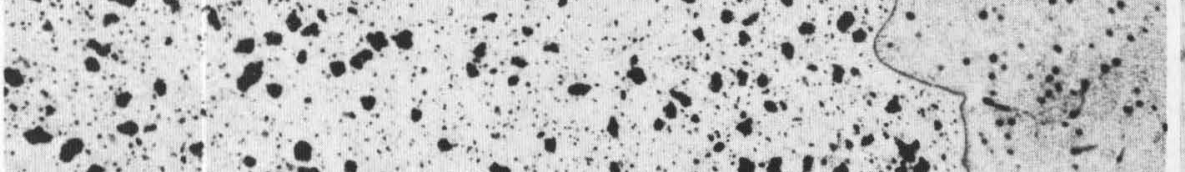

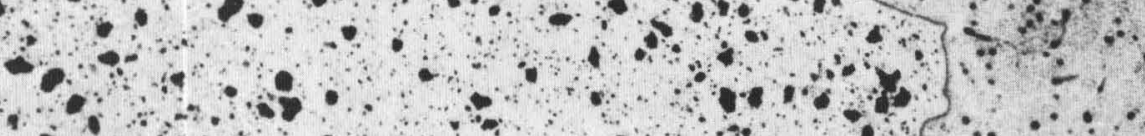

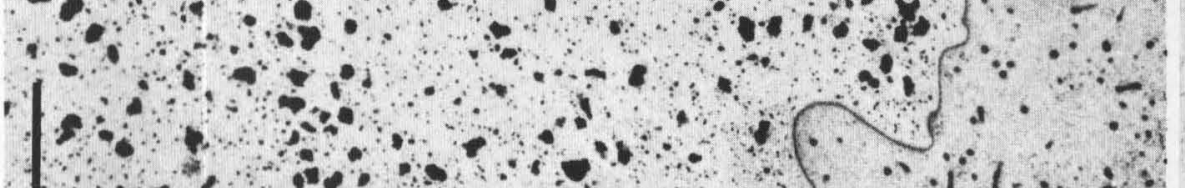
N

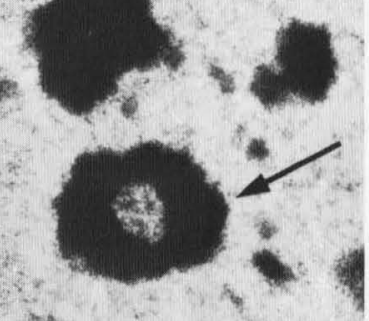

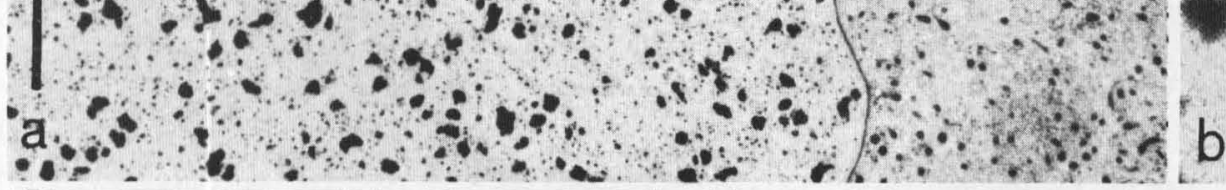

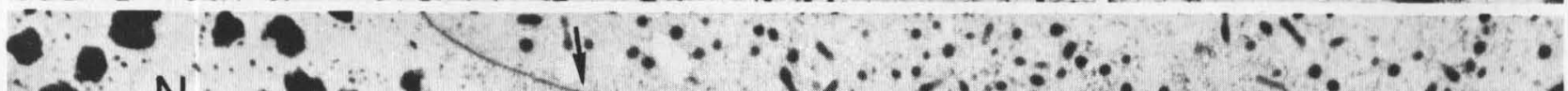

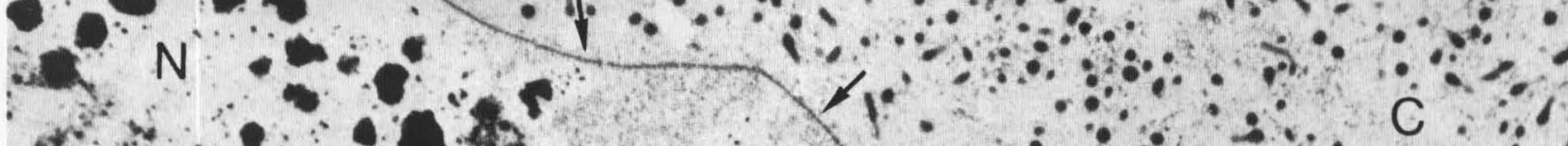
$e^{x^{2}}$ w (5e

Fig. 8. Legend see page 140 
these units, and (3) "light" regions with only very loosely packed, thin filaments that may correspond to the "cavities" or "vacuolizations" described in other forms of nucleoli (for refs. see $[17,43,50]$ ). Within this large "nucleolar aggregate", usually somewhat excentrically located, one often identifies a dense "core" body of a characteristic complex architecture (for details see Figs. 4 and 5). This dense core body is usually more conspicuous during stages in which the whole nucleolar aggregate begins to disperse (Fig. 4). The relative proportions of the components described under (1) to (3) seem to vary; with progressive dispersion of the nucleolar matrix during later stages of oogenesis the looser aspect illustrated in Figure 6 becomes more prominent. A full correlation of the individual components described in this study with those demonstrated by Kato [48] in similar oogenic stages of a series of water beetles is not possible, possibly due to the differences in fixation (Kato used fixation with osmium tetroxide).

The large nucleolar aggregate, in particular its dense core body, frequently reveals close associations with synaptinemal complexes (Figs. 4, 5 and 7; for similar observations in other insects see [51]), indicative of the inclusion of chromosomal regions in this large nucleolar mass which is primarily composed by extrachromosomal material (see Discussion). The ultrastructure of the synaptinemal complexes (Fig. 7) is almost identical to the organization described in other organisms including various insects (for reviews see [51-55]) and terminal associations of these complexes with the nuclear envelope are common (Figs. 5 and 7). Structures resembling the "polycomplexes" described in oocytes and nurse cells of various insects $[51,56,57]$ have not been observed.

During later stages of oogenesis, in particular after the stage 3 of Kato's [48] classification, i.e. during midto-late diplotene, the oocyte nucleus enlarges dramatically, attaining a maximal diameter of about $400 \mu \mathrm{m}$ [25], and the large extra DNA body, the "nucleolar aggregate", disperses (Figs. 1b, 8). At stages of maximal size, the nucleus is rather homogeneously scattered with numerous small bodies that are Feulgen staining-positive and electron-dense (Fig. 8). Among these densely stained particles two size classes can be distinguished, (1) relatively large granules, up to $1.5 \mu \mathrm{m}$ in diameter, which often reveal somewhat irregular contours and internal cavities filled with filamentous coils (Fig. 8) and (2) interspersed small ones that are only $100 \mathrm{~nm}$ in diameter or less. During these later oogenic stages the perinuclear cytoplasm of the oocytes contains mitochondria as well as dense masses which may represent ribonucleoprotein aggregates freshly released from the nucleus (for refs. see [36]; similar perinuclear aggregate structures have been observed in oocytes of other organisms; for refs. see e.g. $[49,58-60])$.

\section{Electron Microscopy of Spread Preparations of Nucleolar Material \\ from Isolated Diplotene Oocyte Nuclei of Dytiscus}

When nuclear contents of early vitellogenic mid-to-late diplotene oocytes of Dytiscus marginalis (100-200 $\mu \mathrm{m}$ in diameter; i.e. oogenic stages such as those shown in Figs. $1 \mathrm{~b}$ and 8 ) are spread and positively stained, with or without additional metal shadowing (see Methods), and examined in the electron microscope, a variety of forms of transcribed nucleolar chromatin are seen (Figs. 9-13; cf. [19].). Transcriptional activity is recognized as matrix units (for terminology see [13, 20, 47, 61] with a dense packing of lateral fibrils, i.e. transcriptional complexes, that are separated from each other by fibril-free intercepts ("apparent spacers"). Only rarely are long intercepts without lateral fibrils observed that exceed the sum of the mean matrix unit length plus the double mean spacer unit length (e.g. Fig. 11f). This indicates that most of the pre-rRNA genes are initiated and

Fig. 9a, b. Survey electron micrographs of a spread and positively stained preparation of nuclear contents isolated from diplotene oocytes of Dytiscus. Transcribed regions ("matrix units") and seemingly non-transcribed ones ("apparent spacer regions") alternate in a pattern which is characteristic for transcribed nucleolar chromatin (for details see text). Well-stretched regions of nucleolar chromatin strands (b) occur next to aggregated units (a). Such aggregations are especially frequent within or between matrix units. In the aggregate of nucleolar chromatin shown in (a) at least 12 individual matrix units can be identified. This aggregate does not exhibit a traceable chromatin axis and also appears to be associated with fragments of the nuclear envelope (some pore complexes denoted by arrows). (b) another form of nucleolar chromatin, i.e. a circular unit containing four genes of pre-rRNA (numbered) which appears well spread and reveals a clearly traceable axis. Scales: $1 \mu \mathrm{m}$. (a) and (b) $\times$ 15,000

Fig. 10a-c. Typical appearance of nucleolar chromatin units containing relatively high (6 to 9) numbers of pre-rRNA genes as revealed in spread preparations of nuclear contents of Dytiscus (for Methods see text). Most of the transcriptionally active nucleolar material appears in the form of isolated units. Such units may represent, or may be derived from, rings containing circular rDNA molecules. Note the general tendency to aggregation of matrix units which frequently results in the formation of twin associations of matrix units laterally adhering to each other. Two short arrows (a): exceptionally long matrix unit $(5.2 \mu \mathrm{m}$, which has to be compared with a mean value of $3.57 \pm 0.52$; for details see text); long arrow in (a): interruption of the axis, probably as a result of preparative stress. Unit in (b): might represent an intact circle. Arrow in (c): region in which fibrilfree sections of the chromatin axis seem to be entangled with each other. Scales: $2 \mu \mathrm{m}$. (a) $\times 11,500$; (b) $\times 10,500$; (c) $\times 16,000$ 

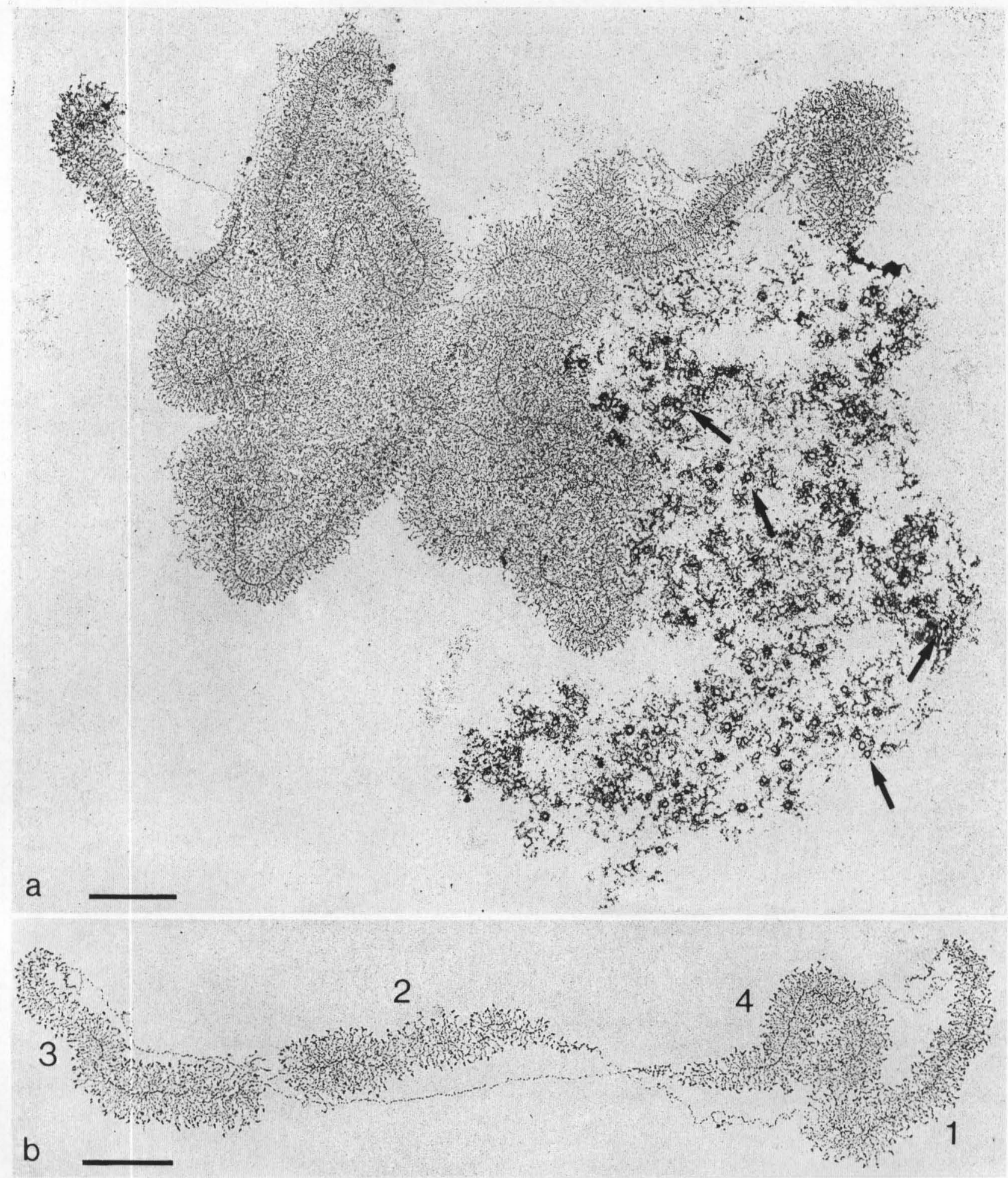

Fig. 9. Legend see page 142 


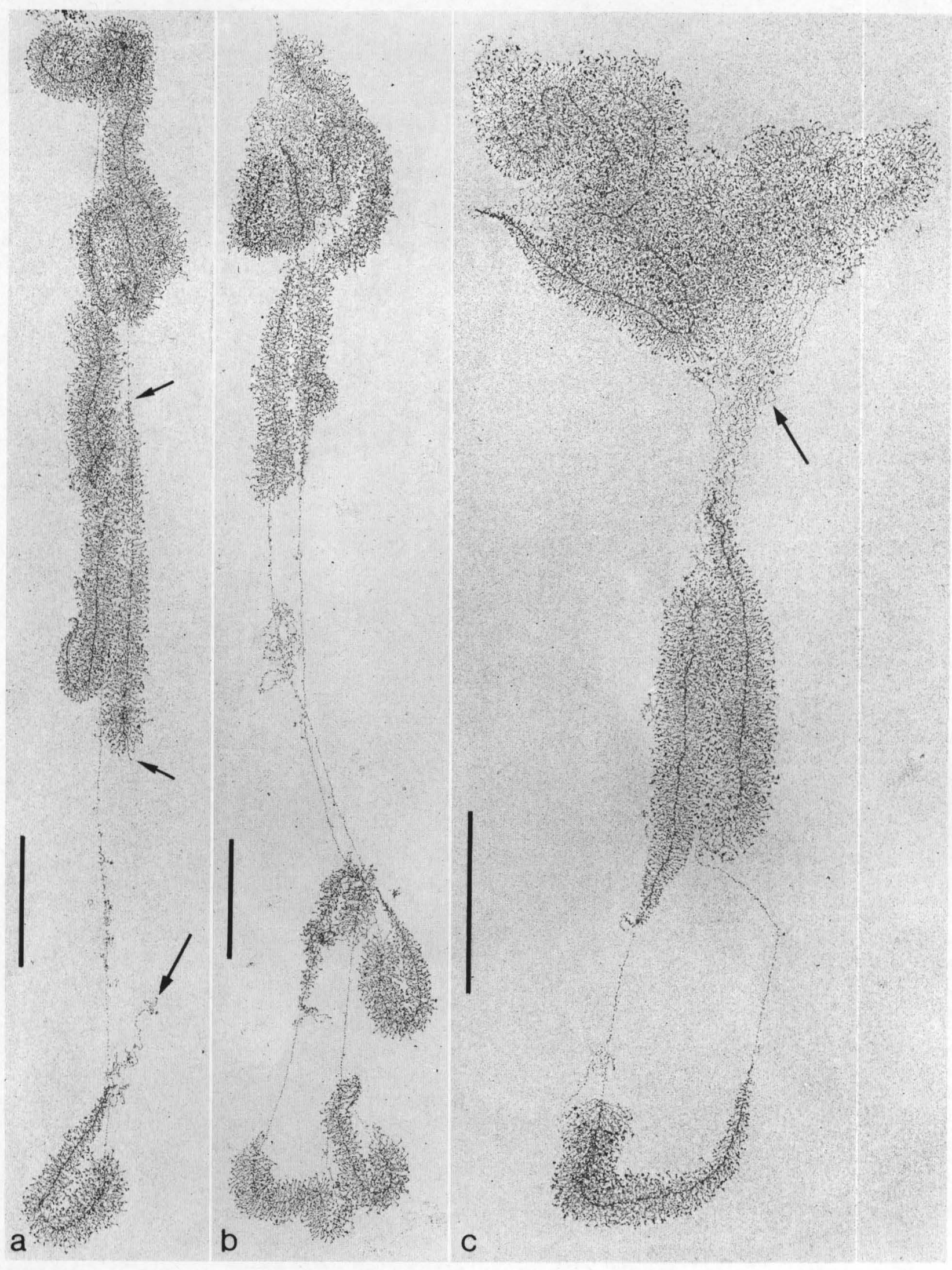

Fig. 10. Legend see page 142 
active in transcription, in accord with the high rRNA synthesis reported in such nuclei from autoradiographic studies (cf. [25, 35, 48]).

Such nucleolar chromatin is found either isolated or attached to other structures such as fragments of the nuclear envelope (Fig. 9a; see also [19]). The majority of the transcriptional units appears either in aggregated (e.g. Figs. 9a, 10c) or extended forms, depending in part on the conditions of the dispersion in the low salt buffer and the centrifugation. Among the relatively extended units of nucleolar material, obviously ring-like ones (e.g. Fig. 9b) are generally more frequent than clearly linear units. In a variable number of such morphological units the chromatin axis is not well traceable or reveals clear interruptions, the latter possibly being due to preparative damage (e.g. Fig. 10). The mean length of the matrix units, $3.57 \pm 0.52$ (S.D.) $\mu \mathrm{m}$, is significantly longer than expected from the size of the pre-rRNA determined by gel electrophoresis ( 2.8 million daltons molecular weight (see [20]). However, significantly shorter (e.g. Fig. 13a) and longer matrix units are occasionally observed; some exceed $5 \mu \mathrm{m}$ in length (e.g. Fig. 10a). The lengths of the fibril-free axial intercepts, the apparent spacer regions, are much more variable and reveal a true heterogeneity.

A detailed quantitative analysis of the patterns of transcriptional units and "apparent spacer" regions is presented elsewhere [20]. The sizes (total circumference) of the ring-like units and correspondingly, the specific number of pre-rRNA genes which they contain, are also variable. Small rings that contain one or two transcriptional units of rDNA are about as frequently found as those containing three and four genes (Figs. 11-13). Larger rings which contain more than four genes are much more rarely found (Fig. 13d; c-f. [20]). The lower frequency of larger rings, however, does not necessarily reflect the distribution in vivo but might well be the result of both the higher susceptibility to breakage and the higher tendency of aggregation and entanglement of larger units.

The relative proportion of pre-rRNA genes contained in circular or linear units was difficult to assess exactly because of the uncertainties concerning axial continuity in a great many of the units. However, the number of ring-like units in spread nucleolar material from Dytiscus oocytes was consistently found to be relatively high. In a total of 25 grids containing material from 120 oocyte nuclei isolated from 12 beetles, an average of $27 \%$ of the identifiable matrix units was observed in clearly circular nucleolar chromatin structures and another $36 \%$ was contained in nucleolar chromatin arrangements which might have been circular but did not allow a clear tracing of the chromatin axis. When we selected the four grids with the highest content of wellextended transcriptional units and intact axes, we found an average of about $70 \%$ of the matrix units in circles. Since such figures must be considered as minimal estimates, this suggests that in vivo most, if not all, of the rDNA must be contained in small circular units (those that contain five pre-rRNA genes or less). This high frequency of circular units of rDNA chromatin observed in transcriptionally active nucleoli correlates well with the relatively high percentage (19\%) of rDNA circles reported by Gall and Rochaix [18] in extracted and purified rDNA from Dytiscus ovarioles.

\section{Light and Electron Microscopy of the Oocyte Nuclei of Acheta domesticus after Fixation in situ}

Early in the oogenesis of Acheta, during premeiotic interphase as well as during pachytene, an enormously large extrachromosomal, Feulgen-positive body containing rDNA is formed, which for some time remains in close association with the chromomere region from which it is derived; it usually also lies close to the nuclear envelope (see Fig. 1c; cf. [2, 26-31, 62-66]). The ultrastructure of the early phase of this DNA-containing

Fig. 11a f. Spread and positively stained examples of small units of nucleolar chromatin from Dytiscus oocytes. Arrowheads: beginning of the specific matrix units. Circular units contain one $(a-c)$ or two ( $d$ and e) pre-rRNA genes. Circle in (f) contains only one matrix unit but may either represent a one-gene unit with an exceptionally long "apparent spacer" region or may contain two genes, only one of which is in statu transcribendi. Note that the relative lengths of the fibril-free intercepts ("apparent spacer regions") appears greatly variable among different rings. Note also that the gradual increase in the lengths of the lateral fibrils is recognized only in the initial part of the matrix units. Scales: $1 \mu \mathrm{m}$. (a) $\times 24,500$; (b) $\times 30,000$; (c) $\times 23,000$; (d) $\times 25,000 ;($ e) $\times 20,000 ;(f) \times 23,000$

Fig. 12a-c. Transcriptional units of extrachromosomal nucleolar chromatin from Dytiscus oocytes contained in circles of three prerRNA genes. Scales: 1 um. (a) $\times 18,000$; (b) $\times 17,500$; (c) $\times$ 21,500

Fig. 13a-d. Further examples of circular, transcriptionally active nucleolar chromatin containing units of amplified rDNA from Dytiscus oocytes. (a) ring containing three matrix units, two of normal length, one very short (matrix unit No. 2 ; ca. $2 \mu \mathrm{m}$ ). (b) and (c) examples of distinct, apparently closed (b) units containing four prerRNA genes. (d) shows an example of a ring containing as many as 9 matrix units. Note the occurrence of some rather long and extended "apparent spacer" regions in (d). Arrowhead points to a site at which a fibril-free axial section makes two sharp bends, obviously as a result of the specific preparation conditions (adhesion). Scales: 1 um. (a) $\times 17,500$; (b) $\times 16,000$; (c) $\times 18,500$; (d) $\times 9500$ 
a

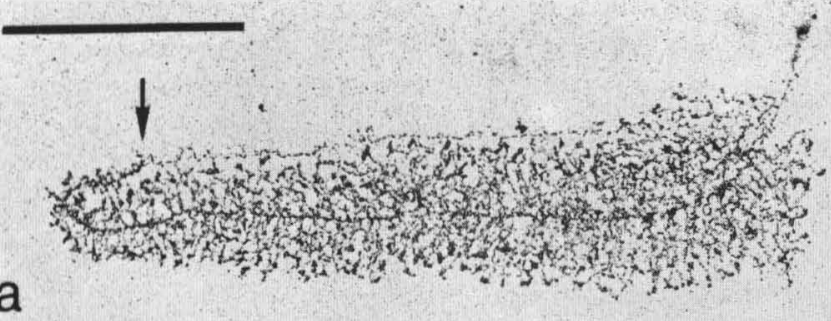

b

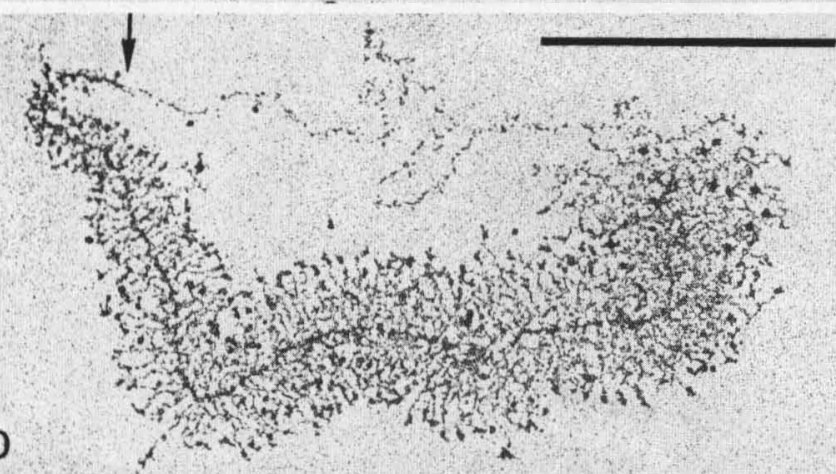

c

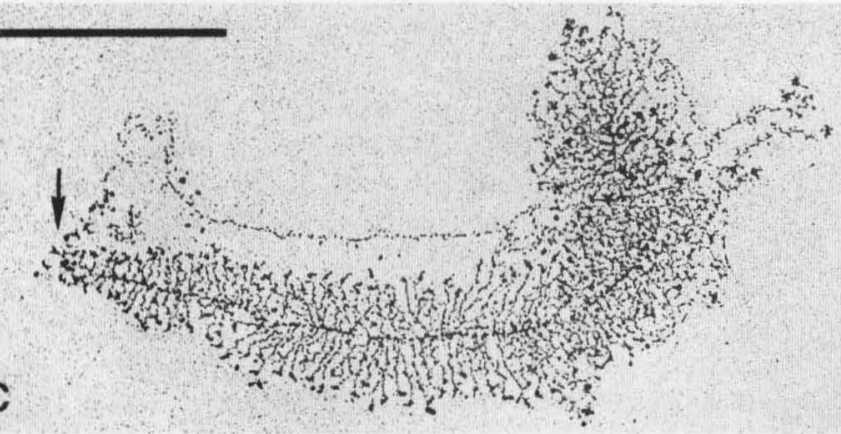

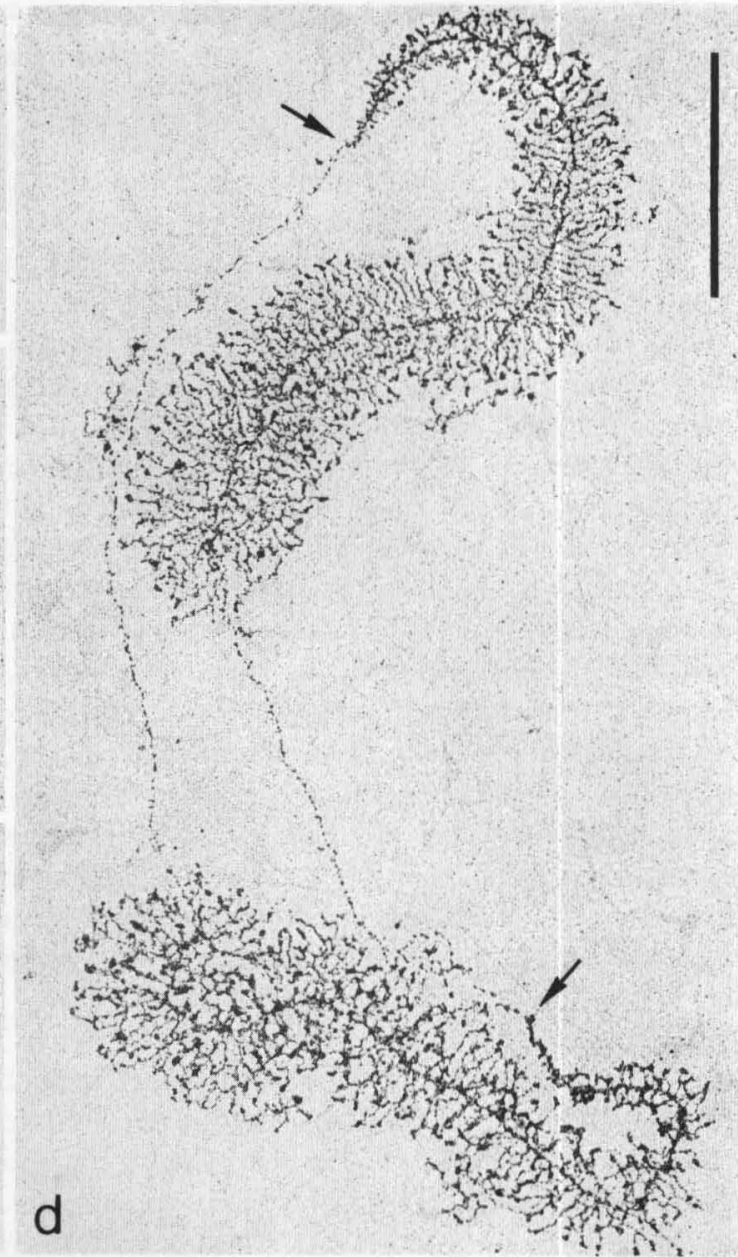

ins

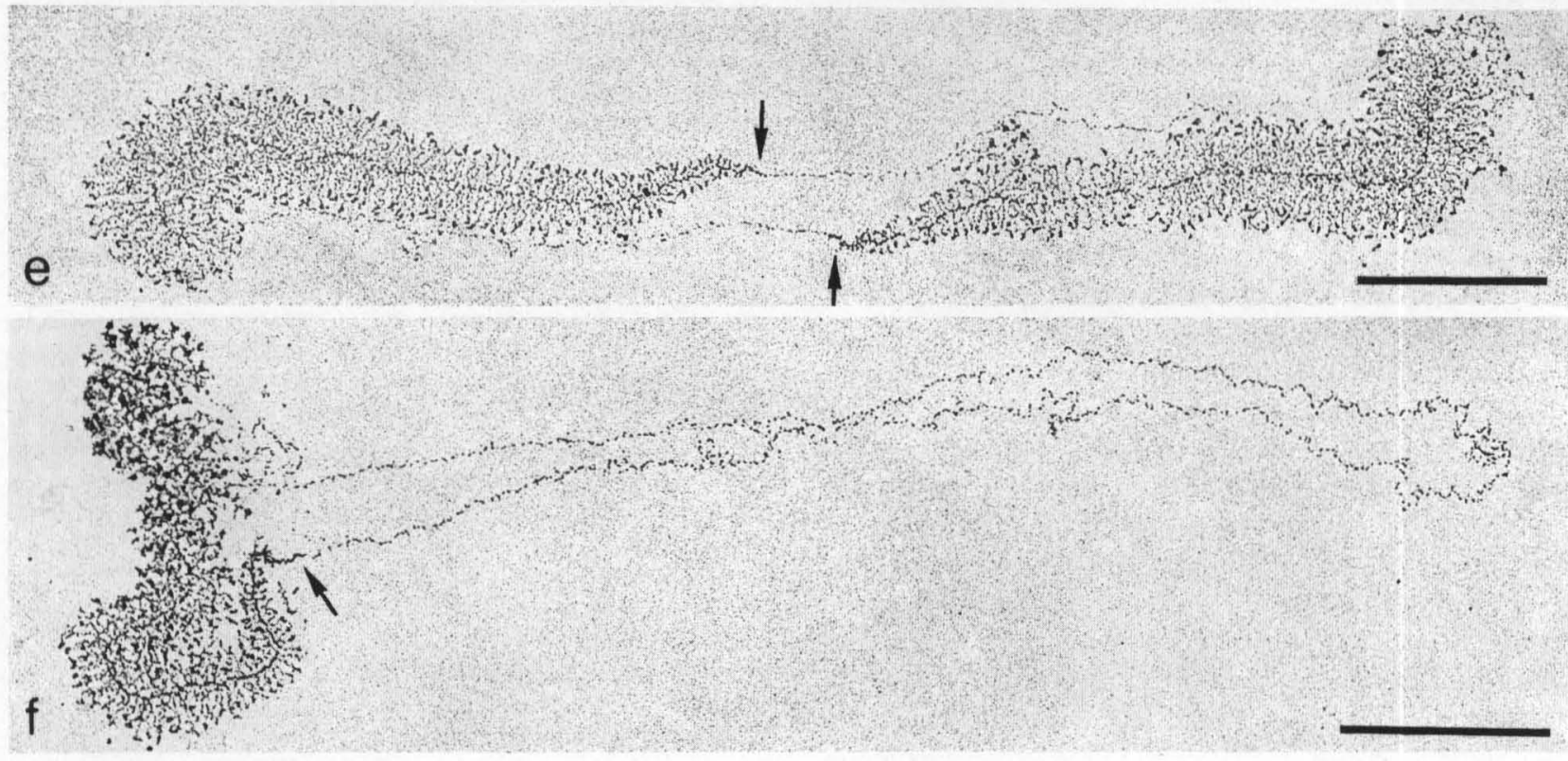

Fig. 11. Legend see page 145 


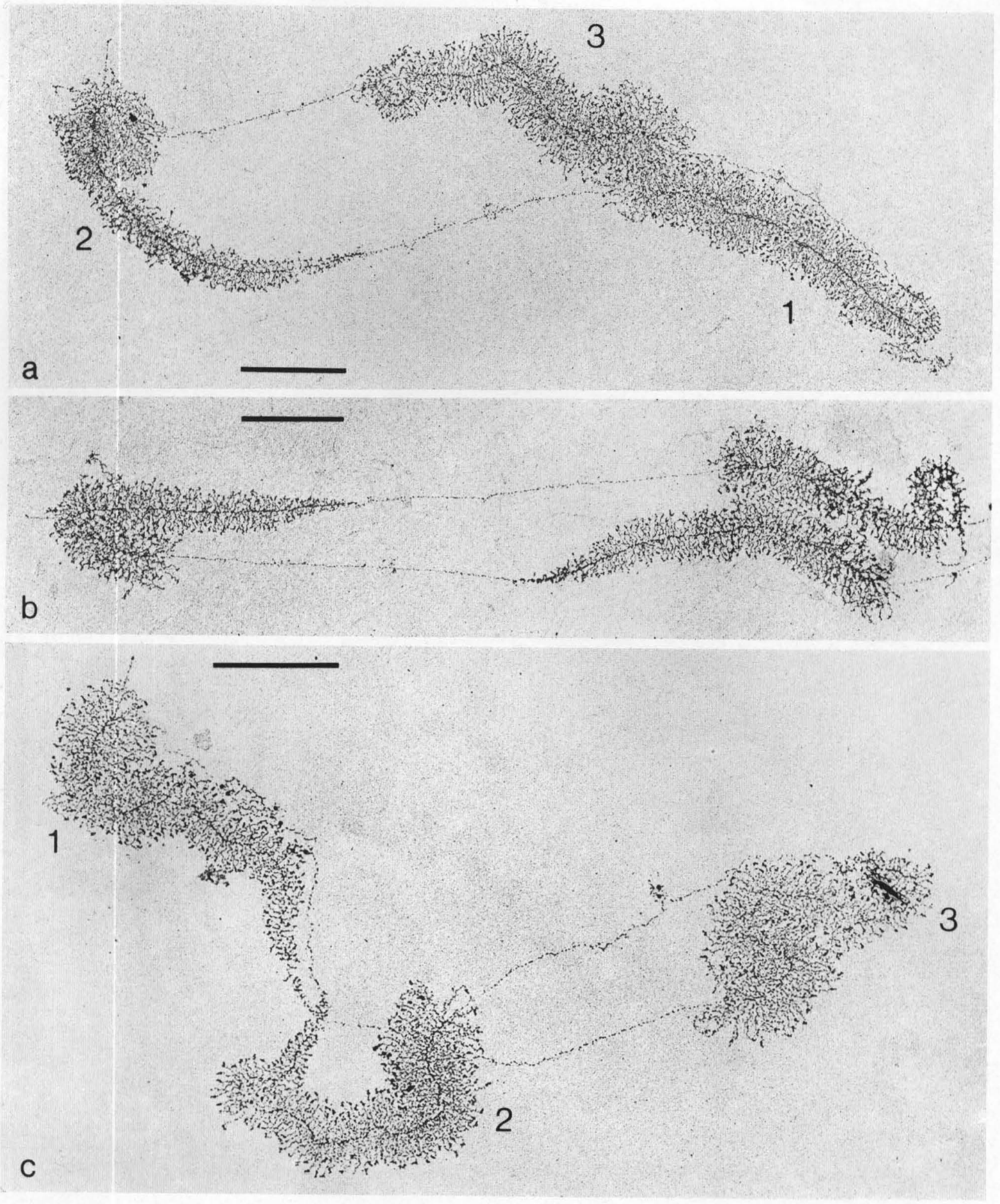

Fig. 12. Legend see page 145 


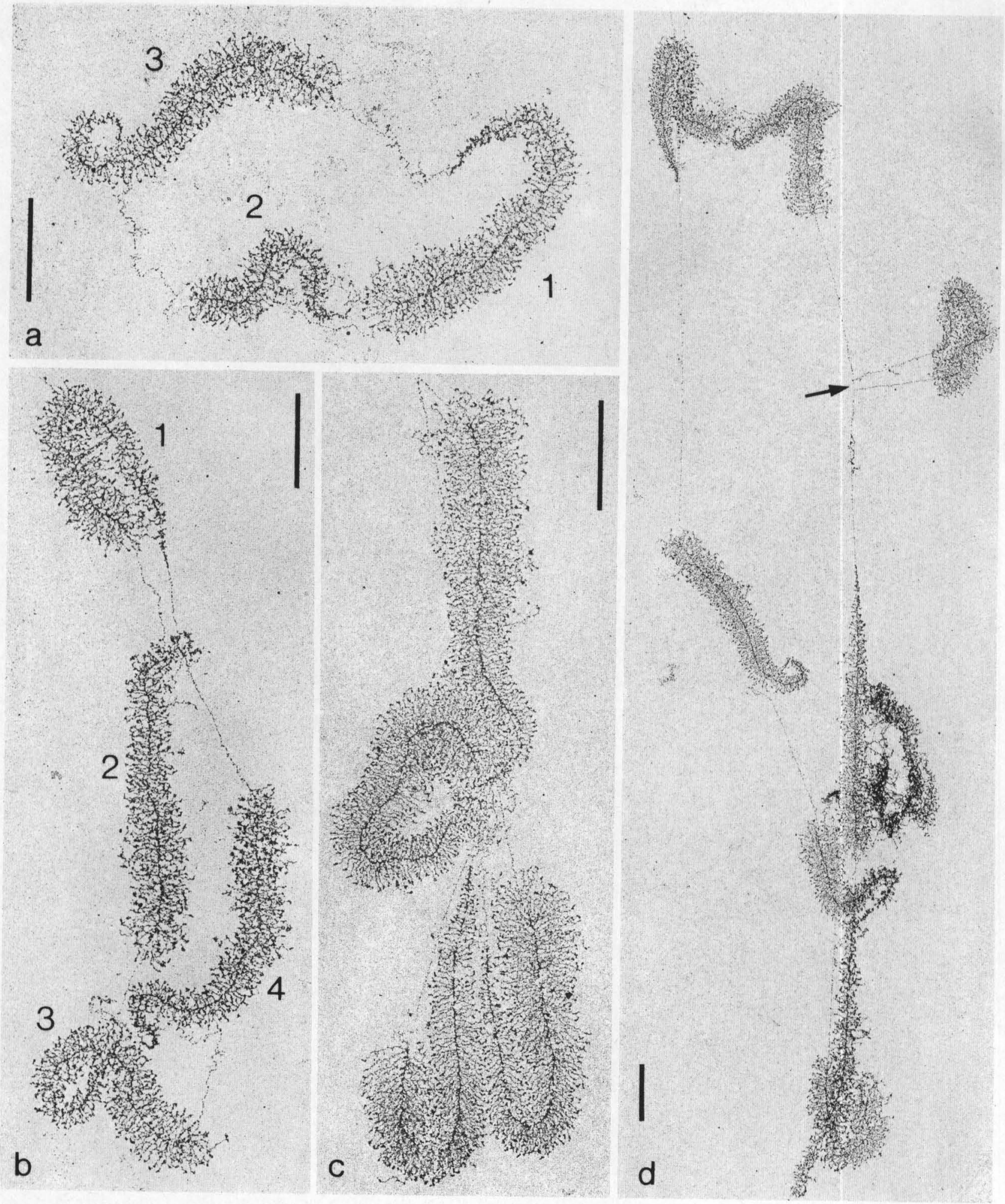

Fig. 13. Legend see page 145 


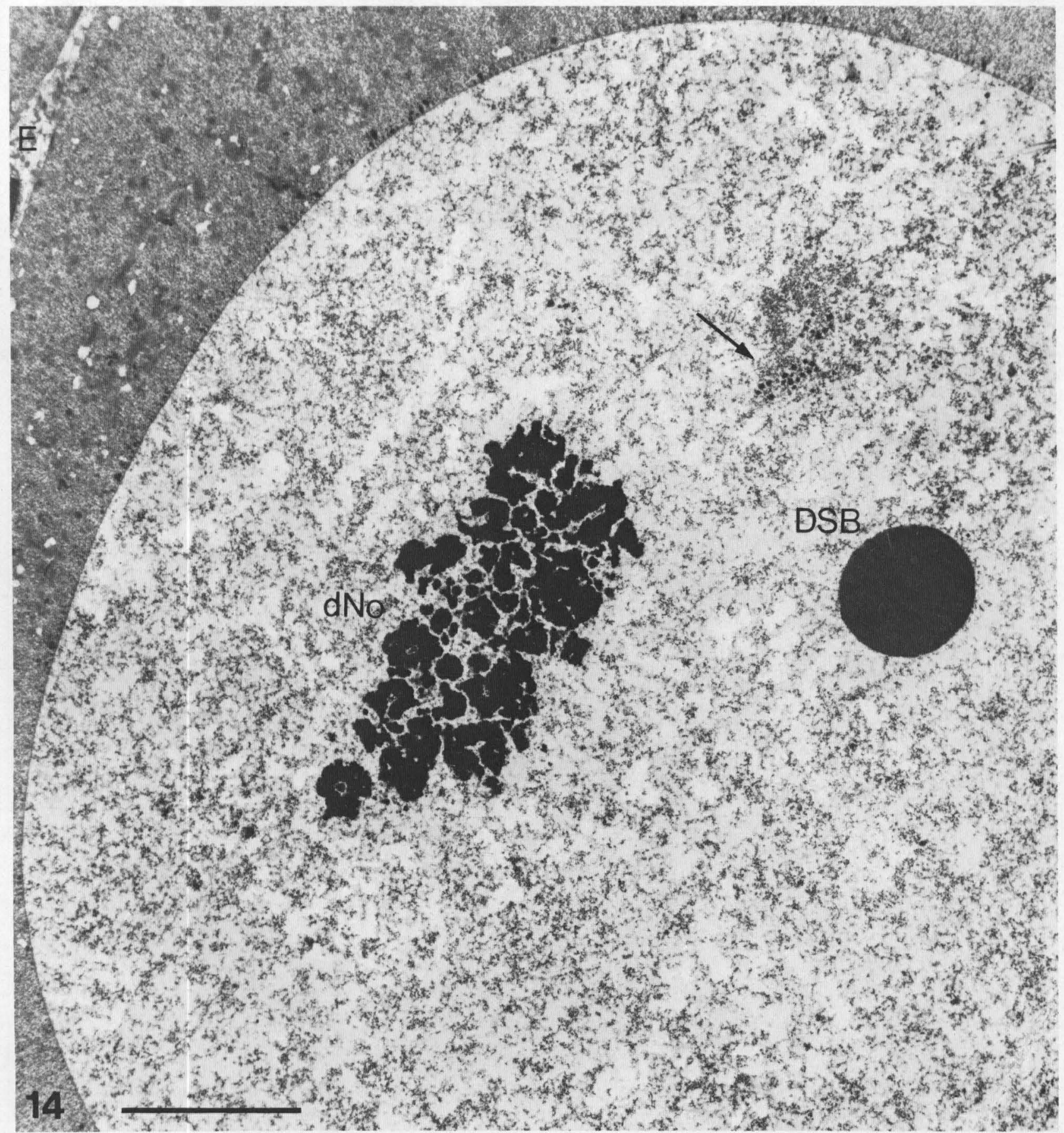

Fig. 14. Electron micrograph of an ultrathin section showing a part of the oocyte nucleus of Acheta domesticus at early diplotene. Four structural components are recognized in the nuclear interior: (i) the dense nucleolar aggregate ( $d N o$ ), (ii) the dense nucleolar body ( $D S B$ : secondary nucleolar body), (iii) a relatively loose aggregate of filamentous material with some small dense granules $(0.1-0.3$ um in diameter; arrow), and (iv) dispersed fibrillar material. Nucleolar chromatin may be contained in all four structures. The cytoplasm (ooplasm) is densely stained, primarily due to the high stainability of the ribosomes and the mitochondria. E: epithelial cell. Scale: $5 \mu \mathrm{m}$. Magnification, $\times 5800$ 


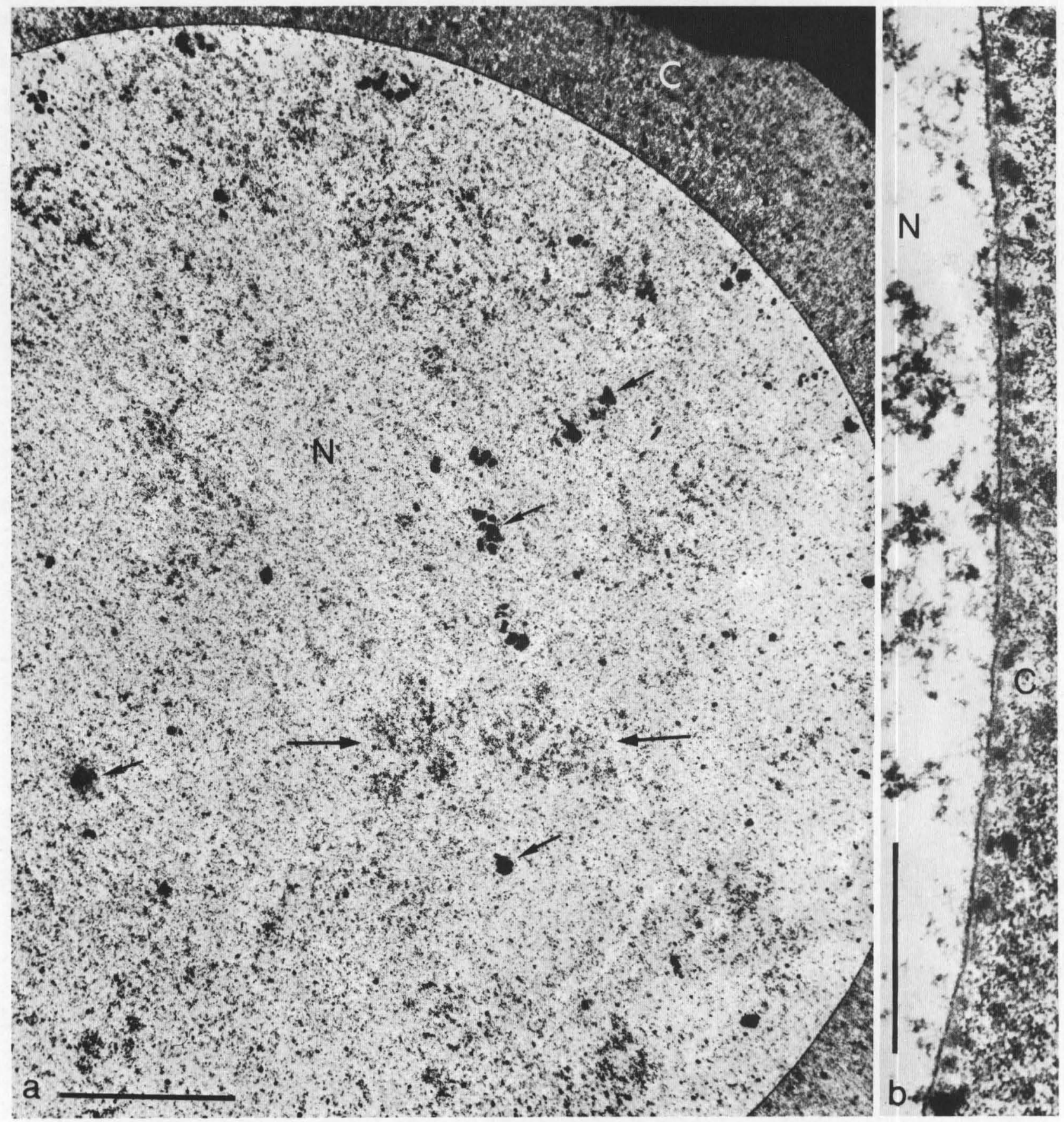

Fig. 15a, b. Acheta oocyte nucleus $(N)$ at a mid-to-late diplotene stage showing the dispersed form of most of the nucleolar material. Some of the remaining dense subunits are denoted by short arrows. Long arrows point to relatively loose fibrillar aggregates that may represent chromosomal material. (b) peripheral zone of such an oocyte at higher magnification. Note the association of nucleoplasmic strands of fibrils with nuclear envelope, in particular at pore complexes, and occurrence of numerous small, dense aggregates in the perinuclear cytoplasm. (C: cytoplasm). Scales: $10 \mu \mathrm{m}$ (a) and $1 \mu \mathrm{m}$ (b). (a) $\times 2800$; (b) $\times 33,000$

Fig. 16a-d. Morphological units of transcriptionally active nucleolar chromatin from diplotene nuclei of oocytes of $A$ cheta domesticus as revealed in the electron microscope after spreading and positive staining with (d) and without $(a-c)$ subsequent metal shadowing. While many of such units appear as densely aggregate clusters of matrix units without identifiable and traceable axis (a) others are more extended and seem to represent closed, possibly ring-like units $(\mathrm{b}-\mathrm{c}$ ) in which fibril-free axial sections connect the matrix units. However, probably due to the adherence of fibrillar material of matrix units to each other, the circular nature of axis is still not clearly evident in such aggregated units. Note densely stained terminal granules in matrix units shown in (c). Bars: $1 \mu \mathrm{m}(\mathrm{a}-\mathrm{c})$ and $2 \mu \mathrm{m}$ (d). (a) $\times 21,000$; (b) $\times 19,000$; (c) $\times 29,000$; (d) $\times 23,000$ 


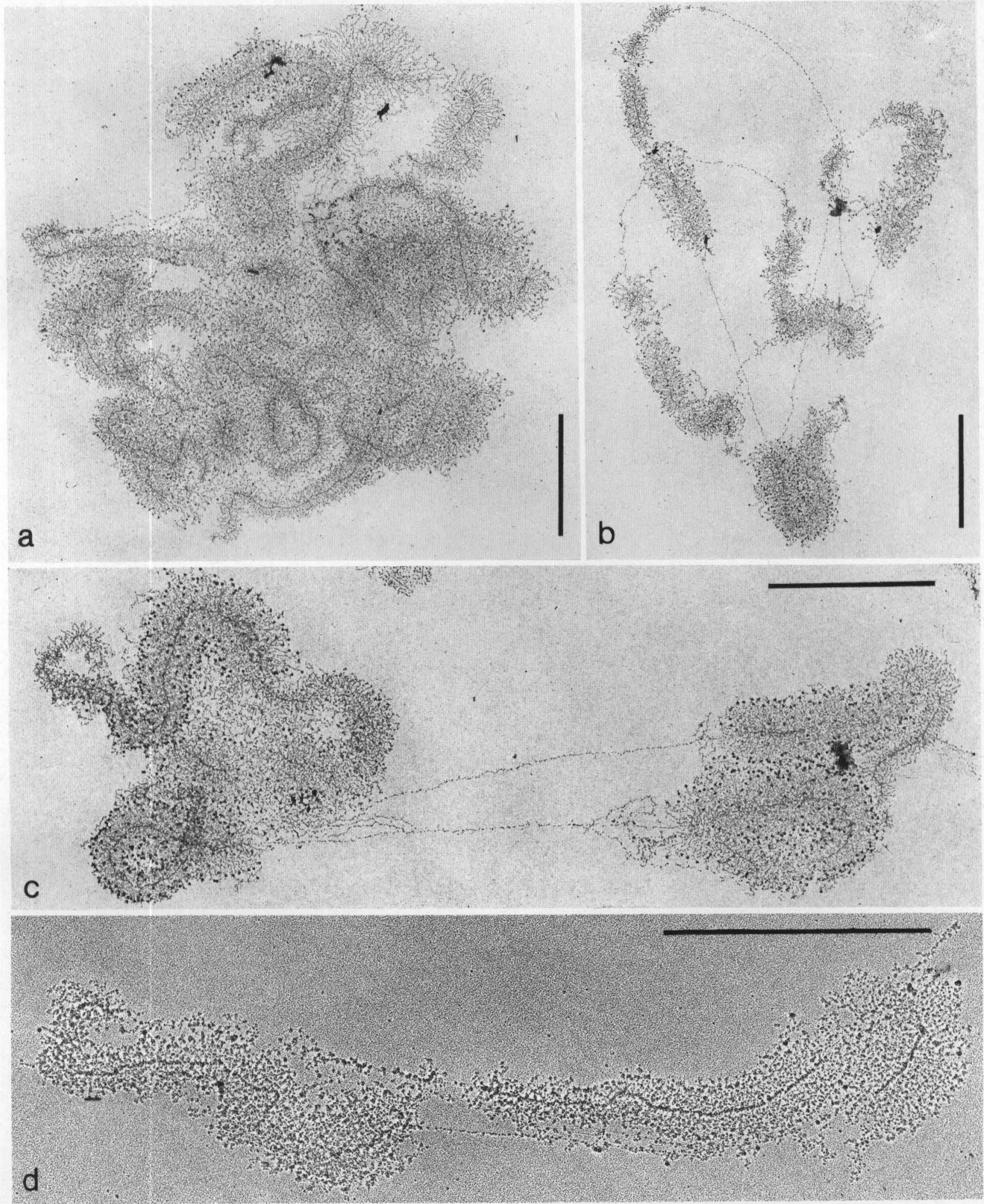

Fig. 16. Legend see page 150 


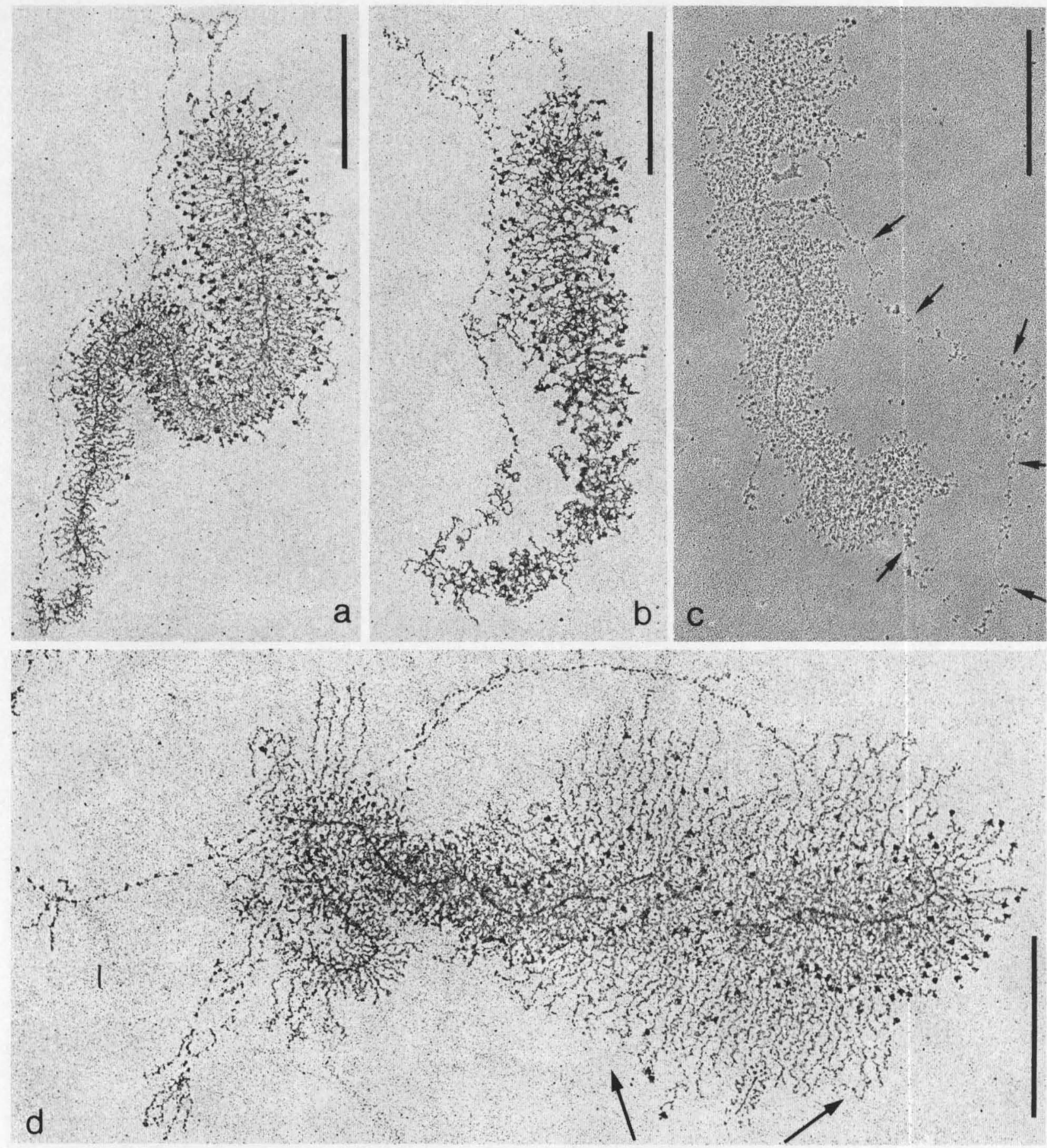

Fig. 17a-d. Ring-like units containing one pre-rRNA gene of extrachromosomal nucleolar chromatin from Acheta oocytes as revealed after spreading and positive staining without (a, b, d) or with (c) additional metal shadowing. Note the great length of both matrix units and fibril-free, "apparent spacer" intercepts. Distinct granules similar to the RNA-polymerase complexes at the bases of the lateral fibrils are sometimes also recognized in fibril-free regions and are especially conspicuous in the shadow-cast preparations (arrowheads in c). Terminal granules at the free ends of the lateral fibrils are particularly well identified in (d). Occasionally, regions with unusually long lateral fibrils are seen, indicative of either a local unravelling and extension, or of a preservation of ribonucleoproteins normally not present in such a position of matrix units (see text). Scales: $1 \mu \mathrm{m}$. (a) $\times 21,500$; (b) and $(\mathrm{c}) \times 23,000 ;(\mathrm{d}) \times 29,000$

Fig. 18a, b. Examples of circular units of nucleolar chromatin from Acheta oocytes containing four (a) or three(b) pre-rRNA genes. The unit shown in (b) has been metal shadow cast after spreading and positive staining. Scales: $1 \mu \mathrm{m}$. (a) $\times 17,500$; (b) $\times 19,000$ 


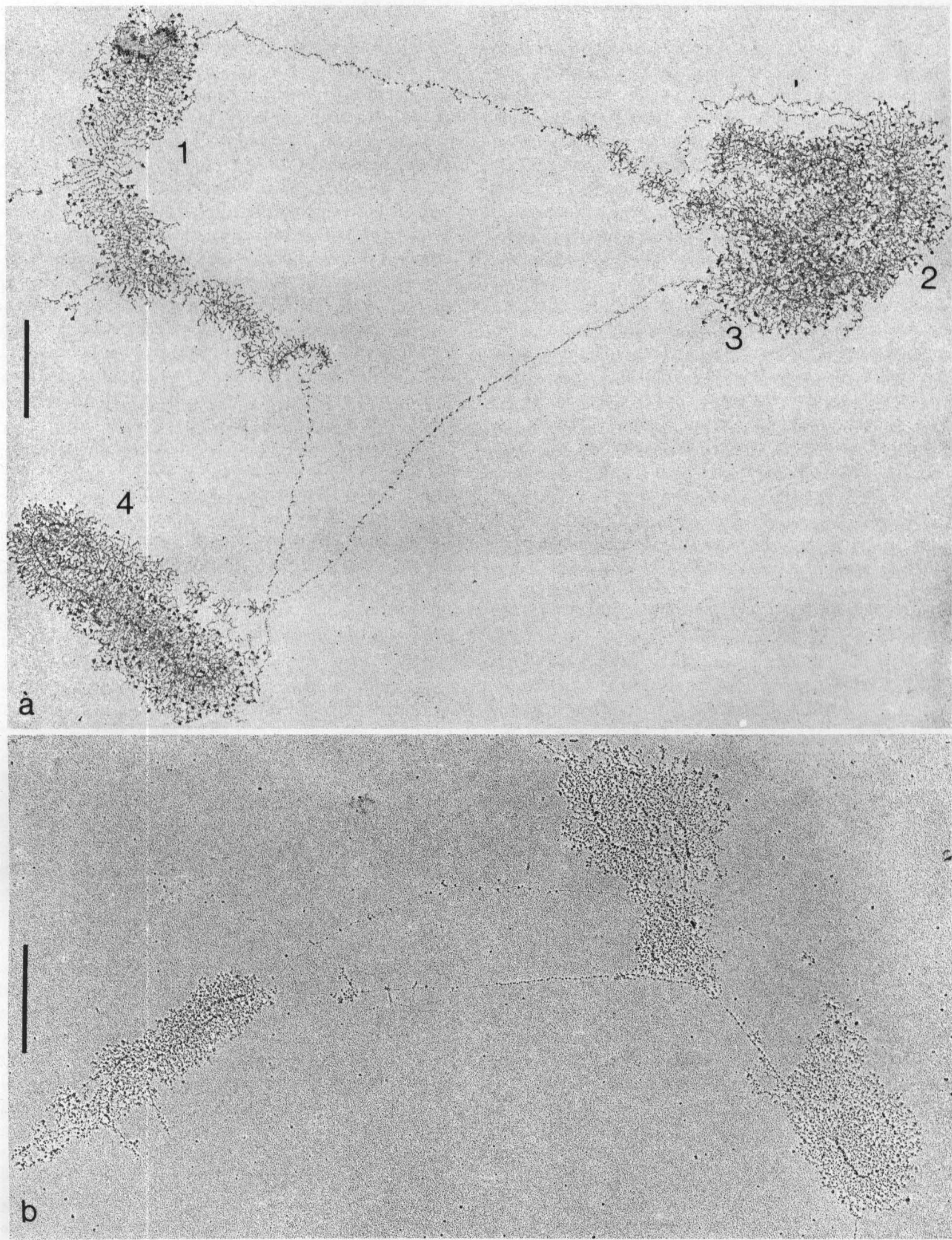

Fig. 18. Legend see page 152 
aggregate body with its complex architecture has been sufficiently well described in a series of articles (see refs. quoted above, and [63, 67-69]). As in the oogenesis of Dytiscus, this aggregate disperses somewhat during midto-late diplotene stages and becomes active in the production of RNA which is predominantly if not exclusively rRNA (Figs. 1d, 14 and 15; see also [25, 27, 64, 68-70]; for similar observations in other gryllid insects see $[25,71])$. This dispersion obviously involves the detachment of a large proportion of the rDNA-containing material from the chromosomal nucleolus organizer regions (see refs. quoted). Detailed descriptions of the individual components identified during diplotene stages are presented in the legends to Figures 14 and 15 and in the aforementioned references. As in vitellogenic Dytiscus oocytes, perinuclear dense masses interpreted as nucleocytoplasmically transported ribonucleoprotein aggregates have also been repeatedly described in Acheta oocytes (Fig. 15b; cf. [70, 72]).

\section{Electron Microscopy of Spread Preparations of Nucleolar Material from \\ Isolated Diplotene Oocyte Nuclei of Acheta}

In spread and positively stained preparations of nuclear contents of diplotene oocytes from Acheta domes- ticus, one recognizes various forms of transcribed prerRNA genes which occur in clusters and are interspersed with apparent spacer intercepts (Figs. 16-18; cf. [44]). The extreme length of the rDNA matrix units $(5.41 \mu \mathrm{m} \pm 0.77$ S.D.) and the spacer regions of Acheta oocytes results in the largest repeating unit hitherto found in any organism (mean value $11.13 \mu \mathrm{m}$; cf. [20, 44, 73]; cf. however, the data for Amoeba in [74]). Nucleolar matrix units of $A$ cheta oocytes are further characterized by exceptionally large and heavily stained terminal granules of the lateral fibrils (Fig. 16c, 17a and d, 18a; cf. [44]). Occasionally, one finds regions within matrix units which are covered with disproportionately long lateral fibrils (Fig. 17d), suggesting local unravelling of terminal granule material or omission of cleavage steps that normally occur in the nascent fibrils (for detailed discussion see [61]).

The majority of the nucleolar masses from Acheta oocytes appeared somewhat aggregated and did not allow a clear tracing of the chromatin axis (e.g. Fig. 16a-c; cf. [44]). However, a small and variable proportion of the morphological units identified in the electron microscope seemed to represent circular strands containing transcribed rDNA. This identification was expecially facilitated in the smallest nucleolar units, i.e. rings which contain only one or two pre-rRNA

(a)
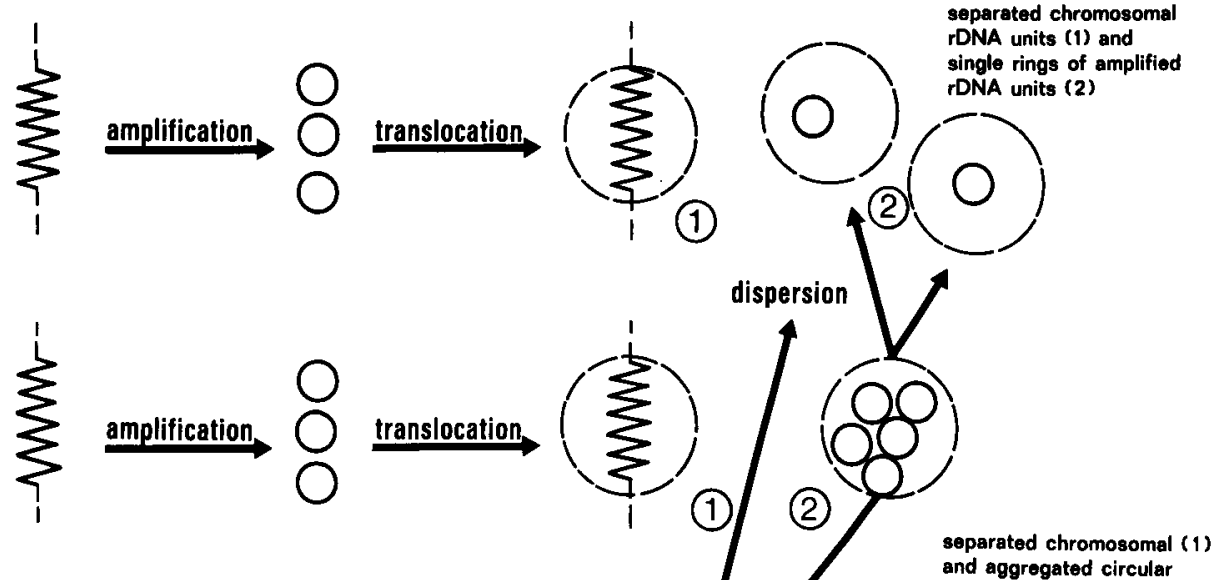

and aggregated circular

(b)
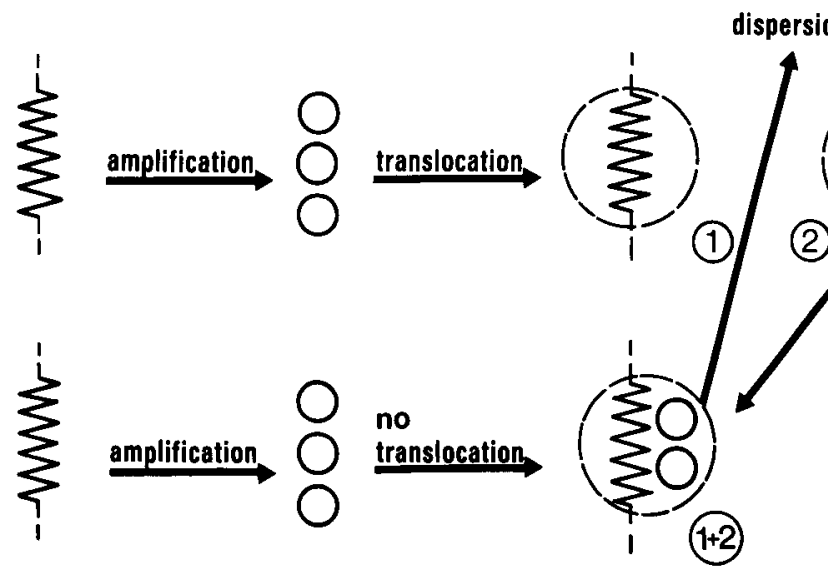

amplified rDNA ( 2 ) units

fused chromosomal and

circular amplified

rDNA units

Fig. 19a-c. Schematic diagram presenting hypothetical changes of the structural association of the amplified nucleolar chromatin here assumed to be primarily contained in ring units. Amplified rings (circles and 2) may segregate from their origin at nucleolar organizers ( $z i g-z a g$ line and 1$)$ and occur as individual, more or less isolated units (a), or may aggregate with each other after dissociation from organizer locus (b), or may remain associated with nucleolus organizer region of chromosomes (c). Arrows: possible later changes in structural organization such as dispersion that takes place during transcription 
genes (Figs. 16d, 17a-c). The occurrence of rings containing more genes is also strongly indicated (Fig. 18; cf. [20]). This demonstration of in vivo transcribed circular units containing rDNA corresponds with observations of circles of isolated rDNA in these cells (Gall, 1974, pers. comm. and [20]).

\section{Discussion}

The present study shows that most, if not all, of the extrachromosomal rDNA in the oocytes of both the panoistic Acheta domesticus and the meroistic Dytiscus marginalis is made up by rather short strands containing not more than five pre-rRNA genes (cf. [18]; some meroistic ovaries, such as the meroistic-telotrophic ovaries of the milkweed bug, Oncopeltus fasciatus, do not contain significant amounts of amplified rDNA [75]). In both types of oocytes, major parts, if not all, of this rDNA is contained in circles of variable sizes (cf. also $[18,19]$; for details of circle lengths and rDNA patterns of arrangement see also [201). This case is different from that described in amphibian oocytes in which circles are relatively rarely observed (a complete list of the few reports is presented in the Introduction) and the pre-rRNA genes are mostly contained in long, virtually linear units that contain high numbers of repeating units (for refs. see Introduction). Similar long strands of many clustered pre-rRNA genes have also been described in the primary nucleus of the green alga Acetabularia (cf. [43, $76,77]$ ) but the question remains whether in this nucleus these strands represent amplified rDNA. Consequently, the "extra DNA" bodies in Dytiscus and Acheta oocytes have to be visualized as aggregated masses of high numbers of rings. An estimation in Dytiscus, for example, shows that each oocyte contains about 3 million prerRNA genes, assuming an average of $67 \mathrm{pg}$ of rDNA [18]. Considering that most of the Dytiscus rDNA is contained in relatively small circles containing one, two or three genes (this study; cf. also [18, 20]), one may conclude that the Feulgen-positive body seen in early oogenic stages of this beetle represents an agglomerate of approximately one million circular units. A similar estimation may be made in Acheta in which the total amount of pre-rRNA genes may be $84,000,150,000$ or 250,000 depending on the specific value of extra-DNA used (cf. the figures reported by [27, 29]; all these values vastly exceed the number of 1600 genes given in [65]) suggesting that here also the nucleolar aggregate contains a high number of rDNA circles.

Our study also indicates that most, if not all, of these extrachromosomal genes of pre-rRNA are actively transcribed during mid-to-late diplotene and that the density of transcriptional units, i.e. the nascent fibrils with their attached RNA polymerase complexes, is maximal in almost all rings.

The structural concept which is derived from these observations is illustrated in Figure 19. After amplification, the small rDNA-containing units, including the circles, may either (1) remain in association (c) with the nucleolus organizer regions (denoted $I$ in Fig. 19) or (2) may directly ( $a$ and $b$ ) or later detach from the chromomeres from which they are derived and then lie free in the nucleoplasm, either as isolated single units or as extrachromosomal aggregates of nucleolar chromatin (both cases denoted by 2 in Fig. 19). The close association of such amplified rDNA chromatin with the chromosomes is also indicated by the appearance of synaptinemal complexes at the large nucleolar aggregate (see Results; cf. also Fig. 4 in [27]). This leads one to the conclusion that in certain cytological situations such as those described here, a morphologically large and complex "nucleolus" structure represents an aggregate of thousands or even millions of small rings of rDNA-containing chromatin (for related observations of aggregated amplified nucleolar chromatin in amphibian and teleost oogenesis see [5, 78-81]). Interestingly, the nucleolar aggregate in both insect species studied reveals a complex organization and appears to be composed of numerous, more or less regularly arranged subunits (see Results and [67]). The correlation, however, between such nucleolar components identified in thin section and by surface scanning electron microscopy of isolated nucleolar aggregates to the nucleolar units seen in spread preparations is still uncertain.

The possible forces that are involved in the association or dissociation of such small, circular units of amplified nucleolar chromatin remain to be elucidated (cf. also the dispersion and condensation cycle of amplified nucleolar material during amphibian oogenesis; for refs. see [17]).

The predominance of circles in transcribed nucleolar chromatin (this study) as well as in isolated rDNA [18, 20] of diplotene oocytes of the two insects, i.e. several months after the amplification [82], is hardly explained by the rolling circle concept per se; additional assumptions must be made such as cyclization and/or breakage processes (for discussion see [15, 16, 21, 22]). In addition, this concept must be modified to account for other observed phenomena such as supercoiling [15, 20-22] and heterogeneity in the gene-spacer pattern $[20,47,83$, 84]. Yet the involvement of mechanisms others than via "rolling circles" cannot at all be excluded at the moment. 
Acknowledgements: We thank Dipl. Biol. H. Spring for his cooperation in some experiments and Dr. W. Merrit (Purdue University, Lafayette, Ind., USA) for reading and correcting the manuscript. The work has received financial support from the Deutsche Forschungsgemeinschaft (grant Sche 157/2).

\section{References}

1. Gall, J. G.: The genes for ribosomal RNA during oogenesis. Genetics (Suppl. 1) 61, 121, 1969

2. Lima-de-Faria, A.: DNA replication and gene amplification in heterochromatin. In: Handbook of Molecular Cytology. Limade-Faria, A., (ed.), p. 277. Amsterdam: North-Holland Publ. Co. 1969

3. Birnstiel, M. L., Chipchase, M., Speirs, J.: The ribosomal RNA cistrons. Progr. Nucl. Acid. Res. 11, 351, 1971

4. Tobler, H.: Occurrence and developmental significance of gene amplification. In: Biochemistry of Animal Development. Weber, R., (ed.), Vol. III, p. 91. New York: Academic Press 1975

5. Vlad, M.: Nucleolar DNA in oocytes of Salmo irideus (Gibbons). Cell Tiss. Res. 167, 407, 1976

6. Engberg, J., Christiansen, G., Leick, V.: Autonomous rDNA molecules containing single copies of the ribosomal RNA genes in the macronucleus of Tetrahymena pyriformis. Bioch. Biophys. Res. Commun. 59, 1356, 1974

7. Gall, J. G.: Free ribosomal RNA genes in the macronucleus of Tetrahymena. Proc. Natl. Acad. Sci. U.S. 71, 3078, 1974

8. Marcaud, L., Portier, M. M., Milet, M.: Ribosomal RNA gene content in micronucleate and amicronucleate strains of Tetrahymena pyriformis. FEBS Lett. 63, 291, 1976

9. Bohnert, H. J., Schiller, B., Böhme, R., Sauer, H. W.: Circular DNA and rolling circles in nucleolar rDNA from mitotic nuclei of Physarum polycephalum. Europ. J. Biochem. 57, 361, 1975

10. Rochaix, J. D., Bird, A. P.: Circular ribosomal DNA and ribosomal DNA: Replication in somatic amphibian cells. Chromosoma 52, 317, 1975

11. Karrer, K. M., Gall, J. G.: The macronuclear ribosomal DNA of Tetrahymena pyriformis is a palindrome. J. Mol. Biol. 104, 421,1976

12. Engberg, J., Andersson, P., Leick, V., Collins, J.: Free ribosomal DNA molecules from Tetrahymena pyriformis GL are giant palindromes. J. Mol. Biol. 104, 455, 1976

13. Miller, O. L., Beatty, B. R.: Extrachromosomal nucleolar genes in amphibian oocytes. Genetics (Suppl. 1) 61, 133, 1969

14. Angelier, N., Lacroix, J. C.: Complexes de transcription d'origines nucléolaire et chromosomique d'ovocytes de Pleurodeles waltlii et $P$. poireti (Amphibiens, Urodèles). Chromosoma 51, 323, 1975

15. Rochaix, J. D., Bird, A., Bakken, A.: Ribosomal RNA gene amplification by rolling circles. J. Mol. Biol. 87, 473, 1974

16. Hourcade, D., Dressler, D., Wolfson, J.: The amplification of ribosomal RNA genes involves a rolling circle intermediate. Proc. Natl. Acad. Sci. U.S. 70, 2926, 1973

17. Scheer, U., Trendelenburg, M. F., Franke, W. W.: Regulation of transcription of genes of ribosomal RNA during amphibian oogenesis. J. Cell Biol. 69, 465, 1976

18. Gall, J. G., Rochaix, J. D.: The amplified ribosomal DNA of dytiscid beetles. Proc. Natl. Acad. Sci. U.S. 71, 1819, 1974

19. Trendelenburg, M. F.: Morphology of ribosomal RNA cistrons in oocytes of the water beetle Dytiscus marginalis L. Chromosoma 48, 119, 1974
20. Trendelenburg, M. F., Scheer, U., Zentgraf, H., Franke, W. W.: Heterogeneity of spacer lengths in circles of amplified rDNA of two insect species, Dytiscus marginalis and Acheta domesticus. J. Mol. Biol. (in press) 1976

21. Bakken, A. H.: Replication of amplifying ribosomal deoxyribonucleic acid in rolling circles in Xenopus laevis oocytes. J. Histochem. Cytochem. 23, 463, 1975

22. Buongiorno-Nardelli, M., Amaldi, F., Lava-Sanchez, P. A.: Electron microscope analysis of amplifying ribosomal DNA from Xenopus laevis. Exp. Cell Res. 98, 95, 1976

23. Ullmann, S. L.: Oogenesis in Tenebrio molitor: Histological and autoradiographical observations on pupal and adult ovaries. $J$. Embryol. Exp. Morph. 30, 179, 1973

24. Telfer, H. W.: Development and physiology of the oocyte-nurse cell syncytium. Adv. Ins. Physiol. 11, 223, 1975

25. Bier, K., Kunz, W., Ribbert, D.: Struktur und Funktion der Oocytenchromosomen und Nukleolen sowie der Extra-DNS während der Oogenese panoistischer und meroistischer Insekten. Chromosoma 23, 214, 1967

26. Cave, M. D., Allen, E. R.: Extra-chromosomal DNA in early stages of oogenesis in Acheta domesticus. J. Cell Sci. 4, 593, 1969

27. Cave, M. D., Allen, E. R.: Synthesis of nucleic acids associated with a DNA-containing body in oocytes of Acheta. Exp. Cell Res. 58, 201, 1969

28. Cave, M. D.: Localization of ribosomal DNA within oocytes of the house cricket Acheta domesticus (Orthoptera, Gryllidae). J. Cell Biol. 55, 310, 1972

29. Lima-de-Faria, A., Gustafsson, T., Jaworska, H.: Amplification of ribosomal DNA in Acheta. II. The number of nucleotide pairs of the chromosomes and chromomeres involved in amplification. Hereditas 73, 119, 1973

30. Ullman, J. S., Lima-de-Faria, A., Jaworska, H., Bryngelsson, T.: Amplification of ribosomal DNA in Acheta. V. Hybridization of RNA complementary to ribosomal DNA with pachytene chromosomes. Hereditas 74, 13, 1973

31. Lima-de-Faria, A., Nilsson, B., Cave, D., Puga, A., Jaworska, H.: Tritium labelling and cytochemistry of extra DNA in Acheta. Chromosoma 25, 1, 1968

32. Lima-de-Faria, A., Moses, M. J.: Ultrastructure and cytochemistry of metabolic DNA in Tipula. J. Cell Biol. 30, 177, 1966

33. Gall, J. G., MacGregor, H. C., Kidston, M. E.: Gene amplification in the oocytes of dytiscid water beetles. Chromosoma 26, 169,1969

34. Bauer, H.: Die wachsenden Oocytenkerne einiger Insekten in ihrem Verhältnis zur Nuklealfärbung. Z. Zellforsch. 18, 254, 1933

35. Urbani, E., Russo-Caja, S.: Osservazioni citochimiche e autoradiografiche sul metabolismo degli acidi nucleici nella oogenesi di Dytiscus marginalis L. Rend. Ist. Sci. Camerino 5, 19, 1964

36. Ficq, A., Urbani, E.: Cytochemical studies on the oogenesis of Dytiscus marginalis L. Exp. Cell Res. 55, 243, 1969

37. Matuszewski, B., Hoser, P.: Gene amplification and its effect on the structure and function of the oocyte nucleus in the whirligig beetle Gyrinus natator (Gyrinidae, Coleoptera, Adephaga) Experientia 31, 431, 1975

38. Matuszewski, B., Kloc, M.: Gene amplification in oocytes of the rove beetle Creophilus maxillosus (Staphylinidae, Coleoptera, Polyphaga) Experientia 32, 34, 1976

39. Kloc, M.: Extrachromosomal DNA and RNA synthesis in oocytes of Creophilus maxillosus (Staphylinidae, Coleoptera, Polyphaga). Experientia 32, 375, 1976 
40. Gruzova, M. N., Zaichikova, Z. P., Sokolov, I. I.: Functional organization of the nucleus during oogenesis of Chrysopa perla L. (Insecta, Neuroptera). Chromosoma 37, 353, 1972

41. Gaginskaya, E. R., Gruzova, M. N.: Detection of the amplified rDNA in ovarial cells of some insects and birds by hybridization of nucleic acids in situ. Tsitologiya 17, 1132, 1975

42. Sitte, P.: Einfaches Verfahren zur stufenlosen Gewebeentwässerung für die elektronenmikroskopische Präparation. Naturwissenschaften 49, 402, 1962

43. Spring, H., Trendelenburg, M. F., Scheer, U., Franke, W. W., Herth, W.: Structural and biochemical studies of the primary nucleus of two green algal species, Acetabularia mediterranea and Acetabularia major. Cytobiologie 10, 1, 1974

44. Trendelenburg, M. F., Scheer, U., Franke, W. W.: Structural organization of the transcription of ribosomal DNA in oocytes of the house cricket. Nature (New Biol.) 245, 167, 1973

45. Kunz, W.: Funktionsstrukturen im Oocytenkern von Locusta migratoria. Chromosoma 20, 332, 1967

46. Franke, W. W., Scheer, U., Trendelenburg, M. F., Spring, H., Zentgraf, H.: Absence of nucleosomes in transcriptionally active chromatin. Cytobiologie 13, 401, 1976

47. Scheer, U., Trendelenburg, M. F., Franke, W. W.: Transcription of ribosomal RNA cistrons. Correlation of morphological and biochemical data. Exp. Cell Res. 80, 175, 1973

48. Kato, K.: Cytochemistry and fine structure of elimination chromatin in Dytiscidae. Exp. Cell Res. 52, 507, 1968

49. Beams, H. W., Kessel, R. G.: The problem of germ cell determinants. Intern. Rev. Cytol. 39, 413, 1974

50. Busch, H., Smetana, K.: The Nucleolus. New York: Academic Press 1970

51. Rasmussen, S. W.: The meiotic prophase in Bombyx mori females analyzed by three-dimensional reconstructions of synaptonemal complexes. Chromosoma 54, 245, 1976

52. Moses, M. J.: Synaptinemal complex. Ann. Rev. Genet. 2, 363, 1968

53. Moens, P. B.: The fine structure of meiotic chromosome polarization and pairing in Locusta migratoria spermatocytes. Chromasoma 28, 1, 1969

54. Comings, D. E., Okada, T. A.: Architecture of meiotic cells and mechanisms of chromosome pairing. Advan. Cell Molec. Biol. 2, 309, 1972

55. Westergaard, M., Wettstein, D. v.: The synaptinemal complex. Ann. Rev. Genet. 6, 71, 1972

56. Roth, T. F.: Changes in the synaptinemal complex during meiotic prophase in mosquito oocytes. Protoplasma 61, 346, 1966

57. Fiil, A., Moens, P. B.: The development, structure and function of modified synaptonemal complexes in mosquito oocytes. Chromosoma 41, 37, 1973

58. Franke, W. W., Scheer, U.: Structures and functions of the $n u-$ clear envelope. In: The Cell Nucleus. Busch, H. (ed.) Vol. I, p. 219. New York: Academic Press 1974

59. Illmensee, K., Mahowald, A. P., Loomis, M. R.: The ontogeny of germ plasm during oogenesis in Drosophila. Develop. Biol. 49, 40, 1976

60. Mahowald, A. P.: Origin and continuity of polar granules. In: Origin and Continuity of Cell Organelles. Reinert, J., Ursprung, H. (eds.) p. 158. Berlin-Heidelberg-New York: Springer 1971

61. Franke, W. W., Scheer, U., Spring, H., Trendelenburg, M. F., Krohne, G.: Morphology of transcriptional units of rDNA. Evidence for transcription in apparent spacer intercepts and cleavages in the elongating nascent RNA. Exp. Cell Res. 100, 233, 1976
62. Jaworska, H., Lima-de-Faria, A.: Amplification of ribosomal DNA in Acheta. VI. Ultrastructure of two types of nucleolar components associated with ribosomal DNA. Hereditas 74, 169,1973

63. Kunz, W.: Die Entstehung multipler Oocytennukleolen aus akzessorischen DNS-Körpern bei Gryllus domesticus. Chromosoma 26, 41, 1969

64. Jaworska, H., Avanzi, S., Lima-de-Faria, A.: Amplification of ribosomal DNA in Acheta. VII. Binding of $\mathrm{H}^{3}$-actinomycin to DNA in the nucleus and cytoplasm. Hereditas 74, 205, 1973

65. Pero, R., Lima-de-Faria, A., Ståhle, U., Granström, H., Ghatnekar, R.: Amplification of ribosomal DNA in Acheta. IV. The number of cistrons for $28 \mathrm{~S}$ and $18 \mathrm{~S}$ ribosomal RNA. Hereditas 73, 195, 1973

66. Hansen-Delkeskamp, E.: Satelliten-Desoxyribonucleinsäure in Gonaden und somatischem Gewebe von Acheta domestica L. $Z$. Naturforsch. 24b, 1331, 1969

67. Lima-de-Faria, A.: The three dimensional organization of the amplified ribosomal DNA complex in Acheta. Proc. Natl. Acad. Sci. U.S. 71, 4778, 1974

68. Favard-Séréno, C.: Evolution des structures nucléolaires au cours de la phase d'accroissement cytoplasmique chez le grillon (Insecte, Orthoptère). J. Microscopie 7, 205, 1968

69. Allen, E. R., Cave, M. D.: Cytochemical and ultrastructural studies of ribonucleoprotein containing structures in oocytes of Acheta domesticus. Z. Zellforsch. 101, 63, 1969

70. Cave, M. D., Allen, E. R.: Synthesis of ribonucleic acid in oocytes of the house cricket (Acheta domesticus). Z. Zellforsch. 120, 309, 1971

71. Cave, M. D., Allen, E. R.: Nucleolar DNA in oocytes of crickets: Representatives of the subfamilies Oecanthinae and Gryllotalpinae (Orthoptera, Gryllidae). J. Morphol. 142, 379, 1974

72. Allen, E. R., Cave, M. D.: Formation, transport and storage of ribonucleic acid containing structures in oocytes of Acheta domesticus (Orthoptera). Z. Zellforsch. 92, 477, 1968

73. Trendelenburg, M. F., Franke, W. W., Spring, H., Scheer, U.: Ultrastructure of transcription in the nucleoli of the green algae Acetabularia major and A. mediterranea. In: Biochemistry of the Cell Nucleus. Mechanism and Regulation of Gene Expression. Hidvégi, E. J., Sümegi, J., Venetianer, P. (eds.) FEBS Proc. Vol. 33, p. 159. Amsterdam: North-Holland Publ. Co. 1975

74. Murti, K. G.: Electron microscopy of active ribosomal genes in Amoeba proteus. J. Cell. Biol. 67, 300a, 1975

75. Cave, M. D.: Absence of ribosomal DNA amplification in the meroistic (telotrophic) ovary of the large milkweed bug Oncopeltus fasciatus (Dallas) (Hemiptera, Lygaeidae). J. Cell Biol. 66, 461,1975

76. Spring, H., Krohne, G., Franke, W. W., Scheer, U., Trendelenburg, M. F.: Homogeneity and heterogeneity of sizes of transcriptional units and spacer regions in nucleolar genes of Acetabularia. J. Micros. Biol. Cell. 25, 107, 1976

77. Trendelenburg, M. F., Spring, H., Scheer, U., Franke, W. W.: Morphology of nucleolar cistrons in a plant cell, Acetabularia mediterranea. Proc. Natl. Acad. Sci. U.S. 71, 3626, 1974

78. Brachet, J.: La localisation de l'acide thymonucléique pendant l'oogénèse et la maturation chez les amphibiens. Arch. Biol. 51, 151,1940

79. Van Gansen, P., Schram, A.: Evolution of the nucleoli during oogenesis in Xenopus laevis studied by electron microscopy. $J$. Cell Sci. 10, 339, 1972 
80. Gall, J. G.: Differential synthesis of the genes for ribosomal RNA during amphibian oogenesis. Proc. Natl. Acad. Sci. U.S. 60, 553, 1968

81. Coggins, L. W., Gall, J. G.: The timing of meiosis and DNA synthesis during early oogenesis in the toad, Xenopus laevis. $J$. Cell Biol. 52, 569, 1972

82. Davidson, E. H.: Gene Activity in Early Development. New York: Academic Press 1968

83. Wellauer, P. K., Reeder, R. H., Caroll, D., Brown, D. D., Deutch, H., Higashinakagawa, T., Dawid, I. B.: Amplified ribosomal DNA from Xenopus laevis has heterogeneous spacer lengths. Proc. Natl. Acad. Sci. U.S. 71, 2823, 1974

84. Wellauer, P. K., Reeder, R. H.: A comparison of the structural organization of amplified ribosomal DNA from Xenopus mulleri and Xenopus laevis. J. Mol. Biol. 94, 151, 1975
Note Added in Proof. After submission of this article we received a copy of the B.Sc. thesis of M. E. Kidston (Nucleolar DNA in oocytes and nurse cells of Dytiscus marginalis; B.Sc. thesis, University of St. Andrews, Scotland, U.K., p. 1-58, 1968) which was kindly sent to us by Dr. H. C. Macgregor (University of Leicester, England, U.K.). This thesis presents a careful light microscopical and cytochemical study of early stages of oogenesis of Dytiscus marginalis and Colymbetes fuscus as well as an electron microscopic study of ultrathin sections of later stages of oogenesis. In addition, this thesis presents the details of the cytophotometric determinations of nuclear DNA in diploid and in meiotic cells of Dytiscus marginalis that are mentioned in reference [33] of the present article. 